\section{Ankara Üniversitesi Eğitim Bilimleri Fakültesi Özel Eğitim Dergisi}

2022, 23(2), 481-506
SISTEMATIK DERLEME

Gönderim Tarihi: 29.10 .20

Kabul Tarihi: 04.06.21

Erken Görünüm: 18.06.21

\title{
Özel Gereksinimli Öğrencilere Fen Bilimleri Öğretiminde Yanlışsız Öğretim Yöntemlerinin Kullanımı: Sistematik Derleme
}

\author{
Hicran Denizli-Gülboy ${ }^{(D)} 1$
}

\author{
Meral Melekoğlu (iD2
}

$\ddot{\mathbf{O} z}$

Giriş: Özel eğitimde etkili öğretim yöntemlerin kullanılması alanyazında sıkça vurgulanmaktadır. Özellikle akademik becerilerin öğretiminde yanlışsı öğretim yöntemleri oldukça etkilidir. Benzer şekilde fen bilimleri öğretiminde de yanlışsız öğretim yöntemlerinin etkili olduğu görülmektedir. Alanyazında yer alan uygulamaların incelenmesi ve tüm beceri öğretimlerinde olduğu gibi fen konularının öğretiminde de yanlışsı öğretim yöntemleri konusunda gereksinimlerin belirlenmesi gerekmektedir.

Yöntem: Çalışmada, özel gereksinimli öğrencilere fen öğretiminde yanlışsız öğretim yöntemlerinin uygulandığı ve tek-denekli araştırma modellerinin kullanıldığı araştırmalara ilişkin sistematik derleme yapılmıştır. Belirlenen anahtar kelimeler veritabanlarında taranmış ve toplam 19 makale çalışma kapsamında belirli değişkenler açısından betimsel analiz tekniği ile incelenmişsir.

Bulgular: Çalışmaya 2000-2020 yılları arasında ulusal ve uluslararası hakemli dergilerde yayımlanmış araştırmalar dâhil edilmiştir. Araştırmalarda çoğunlukla çoklu başlama ve çoklu yoklama desenlerinin kullanıldığı, araştırmalarda toplam 64 katılımcının yer aldığı, katılımcıların çoğunun zihin yetersizliği ve otizm spektrum bozukluğuna sahip öğrenciler olduğu görülmüştür. Ayrıca; kuvvet ve enerji, enerji dönüşümleri ve çevre kirliliği, canlılar dünyası gibi hedef davranışların öğretimine yer verildiği ve katılımcıların belirlenen hedef davranışları edindiği görülmüştür. Yanlışsız öğretim yöntemlerinden ise sabit bekleme süreli ve eş zamanlı ipucuyla öğretim yöntemlerinin daha yoğun olarak kullanıldığı görülmüştür.

Tartışma: Bu çalışma ile her tür ve düzeyde yetersizliğe sahip özel gereksinimli öğrencilere fen bilimleri gibi akademik becerilerin öğretimi konusunda yanlışsız öğretim yöntemlerinin uygulandığ 1 ve tek-denekli araştırma modellerinin kullanıldığı ulusal çalışmaların sayısının artması beklenmektedir.

Sonuç: Özel eğitimde fen öğretiminde yanlışsız öğretim yöntemlerinin oldukça etkili olduğu görülmektedir. Ayrıca, araştırmaların tek-denekli araştırma yöntemleri kriterlerine uygun olarak gerçekleştirildiği belirlenmiştir.

Öneriler: Öğretmenlerin hizmet içi eğitim programlarına etkili yöntemler konusu eklenebilir. Ulusal alanyazında bu konuda uygulamalar ve çalışmalar artırılabilir.

Anahtar sözcükler: Özel eğitimde fen öğretimi, yanlışsız öğretim yöntemleri, tek-denekli araştırma modelleri, otizm, zihin yetersizliği, fen bilimleri.

Atıf için: Denizli-Gülboy, H., \& Melekoğlu, M. (2022). Özel gereksinimli öğrencilere fen bilimleri öğretiminde yanlışsı öğretim yöntemlerinin kullanımı: Sistematik derleme. Ankara Üniversitesi Eğitim Bilimleri Fakültesi Özel Eğitim Dergisi, 23(2), 481-506. https://doi.org/10.21565/ozelegitimdergisi.833253

${ }^{1}$ Uzman, Eskişehir Osmangazi Üniversitesi, Eğitim Bilimleri Enstitüsü, E-posta: hicrandnzl@hotmail.com, https://orcid.org/0000-0001-6732-1536

${ }^{2}$ Sorumlu yazar: Dr. Öğr. Üyesi, Eskişehir Osmangazi Üniversitesi, Eğitim Fakültesi, E-posta: meralmelekoğlu@gmail.com, https://orcid.org/0000-0003-4349-9959 


\section{Giriş}

Geçmişten günümüze özel gereksinimli öğrencilerin (ÖGÖ) eğitim süreci değerlendirildiğinde; yasal düzenlemeler, eğitim ortamlarında yapılan düzenlemeler, eğitim-öğretim programları, özel eğitim-öğretim materyalleri gibi birçok alanda iyileşmeler olduğu görülmektedir (Milli Eğitim Bakanlığı [MEB], 2018). Örneğin, MEB Özel Eğitim ve Rehberlik Hizmetleri Genel Müdürlüğü birim sayfasında ÖGÖ’ler için farklı kademe, yetersizlik türleri ve yaş gruplarına yönelik eğitim programları yer almaktadır (MEB, 2020). Buna ek olarak, MEB (2006) yönetmeliği ile MEB (2018) yönetmeliği karşılaştırıldığında, MEB (2018) yönetmeliğinin "kaynaştırma/bütünleştirme süreci ve tanımı, destek eğitim hizmetlerinin sağlanması süreci, erken çocukluk özel eğitim (EÇÖZE) hizmetlerinin sağlanması süreci ile ilgili kararların ÖGÖ’lere yönelik önemli hizmetleri kapsadığı görülmektedir. MEB birim sayfasında son yıllarda geçmiş yıllara göre daha kapsamlı bilgilerin olduğu görülmektedir. Bu hizmetlerle ilgili (ör. 0-3 EÇÖZE hizmet tanımı ve süreci) MEB (2006) yönetmeliğinde daha sınırlı bilgilerin yer aldığı görülmektedir. MEB'in özel eğitim ile ilgili birim sayfası incelendiğinde, özel eğitim uygulamalarında etkili yöntemler, uygulamalar ile ilgili bir bilgiye rastlanmamaktadır (MEB, 2020). Benzer şekilde, alanyazında özel eğitim uygulamalarının öğrenciler üzerinde istendik yönde bir çıktı sağlamasının etkili öğretim yöntemlerinin uygulanmasına bağlı olduğu vurgulanmaktadır (Clements \& Sarama, 2016, Sazak-Pınar \& Merdan, 2016). Alanyazında, özel gereksinimi olan çocuklarla çalışmakta olan öğretmenlerin etkili uygulamalar konusunda haberdar olmadıkları ve eğitim-öğretimde alanyazında yer alan etkili uygulamalara yer vermekte güçlükler yaşadıkları belirtilmektedir (Caseau \& Norman, 1997). Oysaki MEB öğretim programında, öğrenciler arasında bireysel farklılıkların olduğu ifade edilmektedir. $\mathrm{Bu}$ nedenle, bu farklılıklara dikkat edilerek öğretmenlerin, tüm ÖGÖ’lerin uygun becerileri okullarda edinebilmeleri için uygun öğrenme ortamlarını oluşturmaları gerektiği belirtilmektedir (MEB, 2005). MEB, (2020) 2019-2010 örgün eğitim Milli Eğitim İstatistikleri incelendiğinde ÖGÖ’lerin büyük çoğunluğunun (\%74.76) akranlarıyla aynı ortam olan kaynaştırma/bütünleştirme ortamlarında eğitim aldıkları görülmektedir. Bu bilgiler, okullarda ÖGÖ’lere toplumsal uyum ve günlük yaşam becerilerinden ziyade, çoğunlukla akademik becerilerin öğretimin gerçekleştirildiğini göstermektedir. ÖGÖ’lerin öğrenme özellikleri dikkate alındığında, özellikle akademik becerilerin öğretiminde bireyselleştirme ve etkili öğretim yöntemlerinin kullanılması büyük önem taşımaktadır (Dağseven, 2001; SazakPinar \& Merdan, 2016).

ÖGÖ’lerin eğitim programları incelendiğinde akademik beceriler içerisinde oldukça önemli bir yere sahip olan fen bilimleri dersinde yer alan kavramları ve becerileri kazanabilmesi için daha çok zamana, uygulamaya, çeşitli materyaller ve yöntemlerden oluşan bir öğrenme sürecine gereksinimleri olduğu ifade edilmiştir (MEB, 2005). Buna ek olarak alanyazında, ÖGÖ'lerin de tipik gelişim gösteren akranları gibi fen okuryazarı olabilmeleri, günlük yaşamlarında kullanabilecekleri bilgileri içeren fen bilimleri dersine karşı olumlu tutum geliştirmeleri (Çapraz, 2016; Mete, 2016) ve bireysel farklılıklarına uygun, kaliteli bir eğitim yaşantısı sürdürebilmeleri için öğretim süreci içerisinde bazı düzenlemelere ve etkili özel öğretim yöntemlerine gereksinim olduğu belirtilmektedir (Dağseven, 2001; Denizli, 2015; Sinoplu, 2009; Yorke-Servis, 2012). ÖĞÖ’lerin akademik becerilerin öğreniminde yaşadıkları zorluklar, onların fen bilimleri dersindeki öğrenmelerini ve fen bilimleri dersine karşı olan tutumlarını olumsuz yönde etkilemektedir (Scruggs vd., 1998). Dolayısıyla öğrenme ortamları oluşturulurken ve öğretim planlanırken ÖGÖ’lerin bireysel farklılıkları dikkate alınarak, onların bilgi ve becerilerini sergileyebilmesine ve geliştirebilmesine olanak sağlanmalıdır (Zorluoğlu \& Sözbilir, 2017; Villanueva vd., 2012). Okçu ve Sözbilir (2017) çalışmalarında, öğrencilerin bireysel özelliklerini dikkate alarak yapılan bir dersin, öğrencilerin öğrenmeleri üzerine olumlu etkiler sağladığını ifade etmektedir. ÖGÖ’lerin bireysel farklılıklarına uygun olarak hem fen bilimleri hem de diğer derslerde yapılacak uyarlamaların ve seçilecek etkili öğretim yöntemlerinin belirlenmesinde en büyük rol şüphesiz ki öğretmenlere düşmektedir (Okçu ve Sözbilir, 2017). Ancak fen bilimleri öğretmenlerinin ÖGÖ’lerle öğretim yaparken müfredatta, yöntemde ve ders sırasında yapılan etkinliklerde uyarlamalar yapma konusunda sorun yaşadıkları tespit edilmiştir (Caseau \& Norman, 1997). Ayrıca özel eğitim öğretmenleri, lisansta aldıkları fen öğretimine ilişkin derslerin içerik ve saatlerinin yetersiz olduğunu, derslerin daha çok teoriye dönük olmasından dolayı ÖGÖ’lere fen kavramlarını öğretirken yapılacak uyarlamalarda sorun yaşadıklarını, fen bilimleri dersine yönelik olarak yeterli materyaller olmadığını ve sınıfın fiziki şartlarının elverişsiz olduğunu ifade etmişlerdir (Dedeoğlu vd., 2004; Denizli, 2015; Tarhan, 2019). Benzer şekilde, özel eğitim öğretmenleri fen öğretimi sırasında karşılaştıkları kavramların karmaşı olmasından dolayı bu kavramların nasıl sunulacağı konusunda yetersizlik yaşadıklarını belirtmektedir (Smith vd., 2013; Tarhan, 2019). Dolayısıyla ÖGÖ’lere fen bilimleri dersini veren hem özel eğitim hem de fen bilimleri öğretmenlerinin bu öğrenciler için belirlenen müfredatı sunarken etkili öğretim yöntemleri uygulamadaki yetkinliklerinin artırılması gerekmektedir (Lynch vd., 2007). Nitekim, öğretim sürecinde, etkili öğretim yöntemlerinin kullanılması diğer becerilerin öğretiminde olduğu gibi fen bilimleri dersinde yer alan konuların ve kavramların öğretiminde de 
bilginin kalıcılığı açısından oldukça önemlidir (Mete vd., 2017). Buradan hareketle, özel gereksinimi olan bireylere yönelik fen bilimleri öğretiminde kullanılan etkili öğretim yöntemlerinin neler olduğunun belirlenmesi (Lynch vd., 2007) ve özel eğitimde kullanılan öğretim yöntemlerin tutarlı ve sistematik olarak uygulamaya geçirilmesi (Tekin-İftar \& Kırcaali-İftar, 2012) oldukça önemlidir.

ÖGÖ’lere fen bilimleri konularının (Lynch vd., 2007) ve özel eğitimde etkili öğretim yöntemlerinin (Tekin-İftar \& Kırcaali-İftar, 2012) neler olduğunun belirlenmesi ve uygulanılması açısından öncelikle alanyazının incelenmesi ve etkililiği kanıtlanmış yöntemlerin uygulamaya koşulması gerekmektedir (Spooner vd., 2011; Tekin-İftar \& Olcay-Gül, 2017). Bu bağlamda, alanyazın incelendiğinde ÖGÖ’lere fen öğretiminde kullanılan öğretim yöntemlerini konu alan özellikle uluslararası birçok çalışmanın olduğu tespit edilmiştir (ör. Spooner vd., 2011; Therrien vd., 2011). Bu araştırmalar hakkında daha fazla bilgiye uluşmak adına özellikle derleme çalışmalarına bakıldığında, Spooner ve diğerleri (2011) gerçekleştirdikleri sistematik derleme çalışmasında, orta ve ağır düzeyde yetersizliği olan öğrencilere fen bilimleri konularının öğretiminde kanıta dayalı uygulamaların neler olduğunu belirlemeyi amaçlamışlardır. Bu amaçla, 1985-2009 yılları arasında yayımlanmış, dâhil etme ölçütlerini karşılayan, 17 tek-denekli araştırma modelini Horner ve diğerleri (2005) tarafından önerilen kalite göstergeleri açısından değerlendirmişler ve 14 araştırmanın yeterli ya da yüksek kalitede olduğunu belirlemişlerdir. Çalışmanın bulguları, sistematik öğretimin (ör. beceri analizi ve sabit bekleme süreli öğretim, ipucunun giderek arttırılması) orta ve ağır düzeyde yetersizliği olan öğrencilere fen bilimleri konularının öğretiminde kanıta dayalı etkili uygulama olduğunu ortaya koymuştur.

Therrien ve diğerleri (2011) gerçekleştirdikleri meta-analiz çalışmasında, özel öğrenme güçlüğü (ÖÖG) olan öğrencilere fen bilimleri konularının öğretiminde etkili uygulamaların neler olduğunu belirlemeyi amaçlamışlardır. Bu amaçla, 1985-2006 yılları arasında yayımlanmış, dâhil etme ölçütlerini karşılayan, 12 grup deneysel araştırmayı incelemişlerdir. Çalışmanın bulguları, sorgulamaya dayalı öğretimin (inquiry-based instruction) ve hatırlatıcı öğretimin (mnemonic instruction) öğrenme güçlüğü olan öğrencilere fen bilimleri konularının öğretiminde oldukça etkili uygulamalar olduğunu göstermektedir.

Spooner ve diğerleri (2012) gerçekleştirdikleri sistematik derleme çalışmasında, ağır düzeyde yetersizliği olan öğrencilere matematik ve fen bilimleri konularının öğretiminde kanıta dayalı uygulamaların neler olduğunu belirlemeyi amaçlamışlardır. $\mathrm{Bu}$ amaçla, 2003-2010 yılları arasında yayımlanmış, çalışmanın dâhil etme ölçütlerini karşılayan, 18 tek-denekli araştırma modelini Horner ve diğerleri (2005) tarafından önerilen kalite göstergeleri açısından değerlendirmişler ve araştırmaların tamamının yüksek kalitede olduğunu belirlemişlerdir. Çalışmanın bulguları, beceri analizi ve sabit bekleme süreli öğretimin, ağır düzeyde yetersizliği olan öğrencilere matematik ve fen bilimleri konularının öğretiminde kanıta dayalı etkili uygulama olduklarını ortaya koymuştur.

Apanasionok ve diğerleri (2019) gerçekleştirdikleri sistematik derleme çalışmasında, zihin yetersizliği (ZY) ya da otizm spektrum bozukluğu (OSB) olan öğrencilere fen bilimleri konularının öğretiminin hedeflendiği araştırmaları, öğrenci çıktıları, öğretmen ve öğrenci deneyimleri açısından analiz etmişlerdir. Bu amaçla, 20032017 yılları arasında yayımlanmış, dâhil etme ölçütlerini karşılayan, 28 tek-denekli araştırma modelini ve iki grup deneysel araştırmayı Horner ve diğerleri (2005) ve Gersten ve diğerleri (2005) tarafindan önerilen kalite göstergeleri açısından değerlendirmişlerdir. Çalışmanın bulguları, sistematik öğretimin (ör. sorgulamaya dayalı öğretim, beceri analizi ve sabit bekleme süreli öğretim, eş zamanlı ipucuyla öğretim) ZY ya da OSB olan öğrencilere fen bilimleri konularının öğretiminde etkili uygulama olduklarını ortaya koymuşlardır.

Taylor ve diğerleri (2019) ise gerçekleştirdikleri sistematik derleme çalışmasında, OSB olan öğrencilere fen bilimleri konularının öğretiminde etkili uygulamaların neler olduğunu belirlemeyi amaçlamışlardır. Bu amaçla, 2000-2018 yılları arasında yayımlanmış, dâhil etme ölçütlerini karşılayan, 11 tek-denekli araştırma modelini betimsel özellikleri açısından analiz etmişlerdir. Çalışmanın bulguları, OSB olan öğrencilere fen bilimleri konularının öğretiminde; ayrık denemelerle öğretim, doğrudan öğretim, gömülü öğretim, grafik düzenleyiciler, kendini yönetme stratejileri, teknoloji destekli stratejiler ve yanlışsız öğretim yöntemlerinin etkili uygulamalar olduğunu belirlemişlerdir.

Alanyazında ÖGÖ’lere fen öğretiminde kullanılan etkili öğretim yöntemleri koşununda yer alan mevcut sistematik derleme ve meta-analiz çalışmalarının (ör. Apanasionok vd., 2019; Taylor vd., 2019) bulguları genel olarak özetlendiğinde ÖGÖ’lere (ör. OSB, ÖÖG) fen bilimleri konularının ve kavramlarının öğretiminde sistematik öğretimin ön plana çıktığı görülmektedir. Mevcut sistematik derleme ve meta-analiz çalışmalarına dâhil edilen tek-denekli araştırmalardaki katılımcıların büyük çoğunluğunu ZY ve OSB olan çocukların oluşturduğu; bağımlı değişken olarak dünya, evren, gezegenler, fotosentez, maddenin halleri gibi fen konularının öğretiminin hedeflendiği; bağımsız değişken olarak ise beceri analizi, doğrudan öğretim yöntemi, sabit ve artan bekleme süreli 
öğretim yöntemleri gibi yanlışsız öğretim yöntemlerinin uygulandığı ve araştırma yöntemi olarak ise tek-denekli araştırma modellerinin ağıllıklı olarak kullanıldığ tespit edilmiştir (ör. Sazak-Pınar \& Merdan, 2016; Spooner vd., 2011; Taylor vd., 2019). Ulusal alanyazın incelendiğinde ise ÖGÖ'lere fen öğretiminde genel olarak etkili öğretim yöntemleri konusunda oldukça sınırlı çalışma bulunmaktadır (ör. Dağseven, 2001; Denizli, 2015; Sazak-Pınar \& Merdan, 2016). Uluslararası alanyazına göre fen öğretiminde yoğun olarak başvurulan yanlışsız öğretim yöntemleri konusunda ise iki ulusal çalışma tespit edilmiştir (Sazak-Pınar \& Merdan, 2016; Tekin-İftar \& OlcayGül, 2017). Yanlışsız öğretim yöntemleri, kavram ve becerilerin öğretimi esnasında çocuğa olumlu yanıtlar ve alıştırmalar sunarak çocuğun ilgili beceri ya da kavramı edinmesini sağlamaktadır (Tekin, 1999; Tekin-İftar \& Kurcaali-İftar, 2012).

Ulusal ve uluslararası alanyazın incelendiğinde, özel eğitimde fen bilimleri konularının öğretimde genellikle yanlışsı öğretim yöntemlerinin bağımsız değiş̧ken olarak ya tek başına (ör. Tekin-İftar \& Olcay-Gül, 2017) ya da ikinci bir yöntemle (ör. Rivera vd., 2017; Sazak-Pınar \& Merdan, 2016) kullanıldığı görülmektedir. Buna ek olarak, Apanasionok ve diğerleri (2019) ve Taylor ve diğerleri (2019) derlemelerinde belirttiğgi gibi ulaşılan araştırmaların yoğunlukla tek-denekli araştırma modellerinde desenlendiği gözlenmiştir. Bu nedenle ÖGÖ'lere diğer becerilerin öğretiminde olduğu gibi fen bilimleri konularının (Lynch vd., 2007) ve kavramlarının öğretiminde yanlışsız öğretim yöntemlerinin (Tekin, 1999) oldukça etkili olduğu ifade edilmektedir (Spooner vd., 2012). Araştırma modeli olarak ise ÖGÖ’lerin farklı bireysel özelliklere sahip olmaları bakımında özellikle tekdenekli araştırma modelleri ile daha sistematik, yinelenebilir ve etkili sonuçlar elde edildiği görülmektedir (Tekin, 2000). Bu bağlamda, ulusal ve uluslararası alanyazın incelendiğinde, ÖGÖ’lere beceri ve kavram öğretiminde yanlışsı öğretim yöntemlerinin kullanıldığı ve tek-denekli araştırma modellerinin desenlendiği sayısız çalışma bulunmaktadır. Ancak, alanyazın incelendiğinde, özel eğitim alanında fen bilimleri konularının öğretiminde hem genel olarak, etkili öğretim yöntemleri hem de yaygın olarak kullanılan ve etkili öğretim yöntemlerinden biri olan yanlışsız öğretim yöntemleri konusunda ulusal çalışmalar oldukça sınırlıdır (ör. Sazak-Pınar \& Merdan, 2016; Tekin-İftar \& Olcay-Gül, 2017). Alanyazın ise ÖGÖ’lere fen öğretiminde kullanılan etkili öğretim yöntemlerinin belirlenmesinin ve öğretmenlerin bu konudaki yetkinliklerinin geliştirilmesinin oldukça önemli olduğunu vurgulamaktadır (Dağseven, 2001; Lynch vd., 2007; MEB, 2005). Dolayisıyla, akademik bir beceri olan fen bilimlerinin öğretiminde etkili olan yanlışsız öğretim yöntemlerinin uygulanma durumu ya da etkililik durumunun ulusal ve uluslararası alanyazın düzeyinde incelenmesi bağlamında bir sistematik derlemenin yapılmasına gereksinim duyulduğu görülmüştür.

ÖGÖ’lere fen bilimleri gibi akademik becerilerin öğretimi oldukça önemlidir. ÖGÖ’lerin özellikle ZY ve OSB olan öğrencilerin bilişsel özellikleri dikkate alındığında bu öğrencilere akademik becerilerin öğretiminde sistematik, etkililiği kanıtlanmış yöntemlerle uygulanması oldukça önemlidir. Ulusal alanyazın incelendiğinde ÖGÖ'lere çoğunlukla temel kavramların öğretiminin yapıldığı ancak fen bilgisi gibi üst düzey akademik becerilerin öğretimi ile ilgili çalışmaların sınırlı olduğu görülmektedir. Dolayısıyla, özel eğitimde özellikle yetersizlikten ağır düzeyde etkilenmiş ve farklı gelişimsel özelliklere sahip öğrencilerle bilimsel çalışmalar yürütmede önemli araştırma modellerinden biri olan tek-denekli araştırma modelleri ile gerçekleştirilmiş olan ve fen öğretiminde yanlışsız öğretim yöntemlerinin uygulandığı araştırmaların mevcut durumunun sistematik incelenmesinin yapılarak alanyazın gereksiniminin belirlenmesinin, öğretmen ve araştırmacılara kümülatif bir bilginin sunulmasının önemli olduğu düşünülmektedir. Bu çalışmanın amacı, özel gereksinimli öğrencilere 20002020 yılları arasında fen bilimleri konularının ve kavramlarının öğretiminde yanlışsız öğretim yöntemlerinden en az birinin uygulandığı ve tek-denekli araştırma modellerinin kullanıldığı araştırmaların sistematik bir derlemesinin yapılarak belirli değişkenler açısından incelemektir. Bu amaç bağlamında sistematik tarama sonucu ulaşılan 19 araştırma betimsel analiz tekniği kullanılarak katılımcı demografik özellikleri, araştırma modelleri, ortam ve uygulayıcı özellikleri, bağımlı ve bağımsız değişken türleri, uygulama etkililik düzeyi, veri toplama ve analiz süreci, güvenirlik, sosyal geçerlik, izleme ve genelleme değişkenleri açısından incelenmiştir.

\section{Yöntem}

\section{Araștırma Deseni}

$\mathrm{Bu}$ çalışmada, ÖGÖ’lere fen bilimleri konu ve kavramlarının öğretiminde yanlışsız öğretim yöntemlerinden en az birinin kullanılarak tek-denekli araştırma modeliyle gerçekleştirilen araştırmaları belirli değişkenler açısından incelenmek amacıyla sistematik derleme yapılmıştır. Sistematik derleme; araştırma sorularına, bir konuya ya da alana ilişkin yayımlanmış çalışmaların belirli kriterler göz önünde bulundurularak kapsamlı biçimde taranması ve tarama sonucunda elde edilen araştırmaların bulgularının sentezlenerek sunulması 
amaçlanmaktadır (Karaçam, 2013; Zawacki-Richter vd., 2020). Bu çalışmaya belirli ölçütler bağlamında dâhil edilen araştırmalar belirli değişsenler açısından betimsel analiz yaklaşımı ile analiz edilmişstir.

\section{Tarama Süreci}

Çalışmanın sistematik derleme sürecinde, çalışmaya dâhil edilecek araştırmaların belirlenmesinde iki aşamalı bir tarama süreci takip edilmiştir. Birinci aşamada elektronik tarama, ikinci aşamada ise elle tarama gerçekleştirilmiştir. Elektronik tarama sürecinde iki devlet üniversitesi kütüphanesi bünyesinde yer alan EbscoHost, ERIC, JSTOR, SAGE, Premier, Science Direct, Scopus, Springer, Taylor \& Francis ve Wiley veri tabanlarında ve Türkiye Bilimsel ve Teknolojik Araştırma Kurumu Ulusal Akademik Ağ ve Bilgi Merkezi (TÜBİTAK ULAKBİM) veritabanında, belirlenen anahtar sözcükler kullanılarak tarama yapılmıştır. Elle tarama sürecinde ise elektronik tarama sürecinde elde edilen araştırmaların (ör. sistematik derleme ve meta-analiz çalışmaları) kaynakları incelenmiş ve ilgili olduğu düşünülen araştırmalar derleme sürecine dâhil edilmiştir.

Yetersizlik türlerine ve bağımlı değişkene ilişkin anahtar sözcüklerin belirlenmesinde fen bilimleri konuları ve alanyazında (Apanasionok vd., 2019; Taylor vd., 2019) yer alan sistematik derleme çalışmalarında yoğunlukla kullanılan anahtar kelimeler kullanılmıştır. Buna göre Türkçe ve İngilizce iki farklı anahtar sözcük grubu oluşturulmuştur. Türkçe olarak yetersizlikler için; Otizm* ya da OSB ya da "Otizm spektrum bozukluğu*" ya da "Zihin* Yetersizliği" ya da "Gelişimsel gerilik" ya da "Down sendromu" ya da "Asperger sendromu" ya da "Öğrenme güçlüğüdür.*" Bağımlı değişkene iliş̧kin Türkçe sözcükler; Fen bilim* ya da Fizik ya da Kimya ya da Biyoloji ya da Bitki* ya da "İnsan vücudu" ya da Kuvvet* ya da Dünya ya da Elektrik ya da Asit* ya da Kayaçlar ya da Toprak ya da Mıknatıs* ya da Uzay ya da Kimyasal ya da "Buharlaşma" ya da Mevsimler ya da Kütle ya da Gezegenler* ya da "Güneș sistemi" ya da "Canlı organizma*" ya da Hücre* ya da İnsan vücudu* ya da Mantarlar ya da Böcek* ya da "Sıcaklık" ya da "İş" ya da "Yoğuşma" ya da "Bitki hücresi" ya da "Hayvan Hücresi" ya da "Kurbağanın yaşam döngüsüdür."

Yetersizlik türüne ilişkin İngilizce anahtar sözcükler; Autis* or ASD or "Autism spectrum disorder*” or "Intellectual disabilit*" or ID or "Mental retardation" or "Developmental disabilit*" or "Down syndrome" or "Learning disabilit*" or "Learning difficult*" or "Learning impairment*" or "Intellectual deficien*" or "Developmental impairment*" or "Handicap*"dır. Bağımlı değişkene ilişkin İngilizce anahtar sözcükler ise Scien* or Physics or Chemistry or Biology or Plant* or Animal* or "Human bod*" or Material* or Force* or Earth or Electricity or Acid* or Rocks or Soil or Magnet* or Space or Chemical or Weather or Season* or Mass or Planet* or "Solar system*" or "Living organism*" or Cell* or Bodypart* or Fungus or Insect* or Temperature or "Work* or Scientifically" or "Scien* or Enquiry" or "Scien* or Inquiry" or "Scien* or Experiment" or STEM or "Scien* or Model* and Analog* or "Scien* Pattern-seek*" or "Scien* Curriculum" or "Scien* intervention" or "Scien* program*" or "Scien* or Prediction" or "Scien* or Classification" or "Scien*'dir. Her iki anahtar sözcük grubu "AND" bağlacı kullanılarak birleştirilmiş ve belirtilen veri tabanlarında toplu tarama gerçekleştirilmiştir. $\mathrm{Bu}$ tarama sonucunda 3594 araştırmaya ulaşılmıştır. Farklı veritabanlarında ulaşılan 1092 aynı araştırmalar 3594'ten çıkarılmış ve kalan 2502 araştırmanın tarama ekranları "Portable Document Format (PDF)" formatında kaydedilmiştir. Kalan araştırmaların kaynakçaları incelenerek de yedi araştırmaya ulaşılmıştır. Böylece toplam 2509 olan araştırmaların başlıkları ve özetleri okunarak araşıırma kriterleri, araştırmanın dâhil etme ve hariç tutuma kriterleri dikkate alınarak ön eleme sürecinden geçirilmiştir. Ön eleme sürecinin ardından kalan 62 araştırma tam metin okunarak dâhil etme ve hariç tutma ölçütleri açısından incelenmiş ve bu çalışmaya 19 araştırma dahil edilmiştir. Tüm tarama sürecine ilişkin bilgiler Şekil 1'de yer almaktadır.

\section{Dâhil Etme ve Hariç Tutma Ölçütleri}

Çalışmaya 2000-2020 yılları arasında ulusal ve uluslararası hakemli dergilerde yayımlanmış araştırmalar dâhil edilmiştir. Çalışma konusu ile ilgili etkililik bakılan ilk çalışmaların 2000'den itibaren alanyazında yer almaya başlamasından dolayı taramanın başlangıç yılı olarak 2000 seçilmiştir. Sistematik derleme kapsamına alınacak araştırmaların belirlenmesi amacıyla bir takım dâhil etme ve hariç tutma ölçütleri belirlenmiştir. $\mathrm{Bu}$ çalışmanın dâhil etme ölçütleri; (a) araştırmalarda yer alan katılımcılardan en az birisinin yetersizlik tanısı almış olması, (b) bağımlı değişkenlerden en az birinin fen bilimleri alanından seçilmiş olması, (c) bağımsız değişkenin ya da bağımsız değişken gruplarından en az birisinin yanlışsız öğretim yöntemlerinden birisi olması (d) araştırmanın tek-denekli araştırma modeli kullanılarak gerçekleştirilmesi ve (e) hakemli dergilerde yayımlanmış ulusal ya da uluslararası bilimsel bir çalışma olmasıdır. Çalışmanın hariç tutma ölçütleri ise (a) bağımsız değişken(ler)in yanlışsı öğretim yöntemlerinden en az birinin olmaması, (b) araştırmanın tek-denekli araştırma modelleri dışında başka bir araştırma deseni kullanılarak gerçekleştirilmiş olması ve (c) fen bilimleriyle ilişkili metinlerde okuduğunu anlama araştırmalarıdır. 


\section{Verilerin Analizi}

Araștırmaya başlamadan önce, çalışmanın amacı bağlamında ulaşılan makalelerin hangi açılardan çalışmaya dâhil edileceği ve çalışmaya dâhil edilen makalelerin hangi açılardan inceleneceği belirlenmiştir. $\mathrm{Bu}$ bağlamda öncelikle dâhil etme ve hariç tutma ölçütleri belirlenmiştir. Çalışmaya dâhil edilen araştırmalar betimsel analiz yaklaşımı ile analiz edileceği için öncelikle araştırmaların inceleneceği temalar belirlenmiştir. Bu temaların belirlenmesinde; (a) alanyazında yer alan sistematik derlemeler ve meta-analiz çalıșmalarında çoğunlukla kullanılan temalar, (b) Horner ve diğerlerinin (2005) çalışmasında belirtilen tek-denekli araştırmaların kalite göstergeleri ve (c) uygulama temelli bilimsel bir araştırmanın yöntem kısımda yer alan değişkenler incelenerek bir veri kodlama anahtarı oluşturulmuştur. Bu kodlama anahtarında; (a) katılımcı özellikleri (katılımcı sayısı, yaş aralığı, cinsiyet, tanı), (b) uygulayıcı, (c) ortam, (d) araștırma modeli, (e) bağımlı değișken, (f) bağımsız değișken, (g) veri toplama aracı, (h) veri analizi, (1) uygulamanın etkililiği, (i) gözlemciler arası güvenirlik, (j) uygulama güvenirliği, (k) uygulama etkililĭği, (l) sosyal geçerlik, (m) izleme/kalıcılık ve (n) genelleme değişkenleri yer almaktadır. Çalışmaya dâhil edilen araştırmaların tamamı okunarak veriler kodlama anahtarına işlenmiştir.

\section{Şekil 1}

Tarama Süreci Akış Şeması

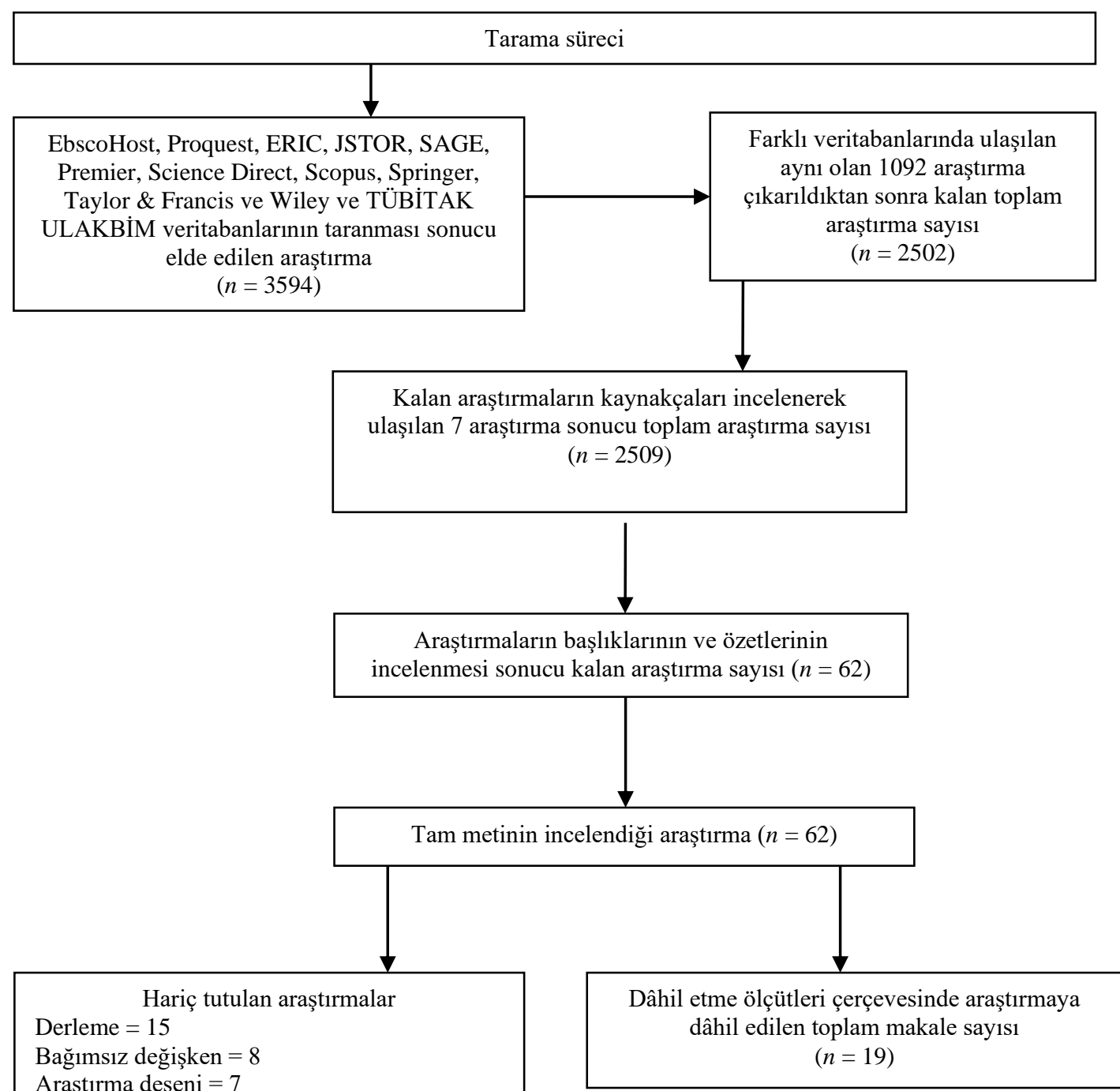




\section{Güvenirlik}

Çalışmada; tarama süreci, dahil etme, hariç tutma süreci ve betimsel analiz sürecine ilişkin güvenirlik çalışmaları ikinci yazar tarafından yapılmıştır. Ulaşılan araştırmaların öncelikle dahil etme ve hariç tutma kriterlerine ilişkin güvenirlik analizi yapılmıştır. Dâhil etme ve hariç tutuma ölçütlerinin uygulanmasına ilişkin kodlayıcılar arası güvenirlik katsayısı \%100 olarak bulunmuştur. Tarama sürecinin güvenirlik analizi ise aynı anahtar kelimelerle gerçekleştirilmiştir. Betimsel analiz sürecinde araştırmaların \%30'u ( $n=6$ araştırma) için gerçekleştirilmiştir. Verilerin \%30'nu belirlemek için tüm çalışmalara bir numara verilmiştir ve bu numaralar bir kavanoza atılıp içerisinden altı çalışma seçilmiştir. Her iki aşama için güvenirlik katsayısı; "Değerlendiriciler arası görüş birliği / (değerlendiriciler arası görüş birliği + değerlendiriciler arası görüş ayrılığı) x 100" formülü kullanılarak hesaplanmıştır. Tarama sürecine ilişkin güvenirlik katsayısı \%100 iken betimsel analiz için güvenirlik katsayıs1 \%98' dir. Görüş ayrılıklarının olduğu durumlara ilişkin değerlendiriciler görüşlerini ifade etmiş ve o görüş ayrılıklarına ilişkin uzlaşma sağlamışlardır. Yazarlardan ikinci araştırmacı araştırma yöntemleri ve özellikle nitel araştırma yöntemleri konusunda yetkindir ve araştırma sürecinde kodlama sürecini ikinci araştırmacı yönetmiştir. İkinci araştırmacı, birinci araştırmacıya ulaşılan araştırmaları incelemek için oluşturulan veri kayıt formuna kodlamaları nasıl yapacağı konusunda uygulamalı bir eğitim vermiştir.

\section{Bulgular}

Bu bölümde çalışmadan elde edilen bulgular sırası ile rapor edilmiştir. Dâhil etme ölçütlerini karşılayan 19 araştırma, araştırma soruları bağlamında betimsel analiz yaklaşımı ile analiz edilmiş ve elde edilen bulgulara bu bölümde yer verilmiştir. Betimsel analiz bulguları Tablo 1'de yer almaktadır.

\section{Katılımcılar ile İlgili Bulgular}

Bu çalışmaya dâhil edilen 19 araştırmada toplam 64 katılımcı yer almış olup bunların 40'i erkek ve 24'ü kız öğrencidir. Araştırmaların tamamında katılımcıların yaşlarına ilişsin bilgi verilmiştir. Katılımcıların yaş ortalamasının 13.1 yaş (ranj = 6-25 yaş) olduğu belirlenmiştir. Araştırmaların yaş gruplarına göre dağılımları analiz edildiğinde, 12 araştırmada katılımcıların 6-13 yaş aralığında (ör. Collins vd., 2007; Greene \& Bethune, 2021; Jimenez vd., 2012); dokuz araştırmada katılımcıların 14-18 yaş aralığında (ör. Britton vd., 2017; Collins vd., 2011; Collins vd., 2017) ve üç araştırmada ise katılımcıların 19 yaş üstü yetişkinlik döneminde (ör. Collins vd., 2007; Collins vd., 2017; McMahon vd., 2015) olduğu bulgularına ulaşılmıştır. Katılımcıların yaş aralıklarının geniş olduğu araştırmalar birden fazla yaş aralığına dâhil edilmiştir (ör. Collins vd., 2007; Collins vd., 2017; Jimenez vd., 2012; Riesen vd., 2003).

Araştırmalarda yer alan katılımcıların yetersizlik türleri incelendiğinde, 39 katılımcının zihin yetersizliği tanısının (ör. Britton vd., 2017; Collins vd., 2017; Jimenez vd., 2009); dokuz katılımcının zihin yetersizliği ve OSB tanısının (ör. Greene \& Bethune, 2021; Jimenez vd., 2014; Knight vd., 2013); 10 katılımcının OSB tanısının (ör. Johnson vd., 2015; McMahon vd., 2015; Tekin-İftar \& Olcay-Gül, 2017); dört katılımcının çoklu yetersizlik tanısının (ör. Riesen vd., 2003; Smith vd., 2013) ve iki katılımcının ise gelişimsel gerilik tanısının (Rivera vd., 2017) olduğu görülmüştür. Farklı yetersizlik türlerinin yer aldığı araştırmalar birden fazla tanı grubunda yer almıştır (ör. Collins vd., 2011; Riesen vd., 2003; Rivera vd., 2017).

\section{Uygulayıcılar ile İlgili Bulgular}

Araştırmaların tamamında uygulayıcılara ilişkin bilgi verilmiştir. Araştırmalarda yer alan uygulayıcılara ilişkin bilgiler incelendiğinde, dokuz araştırmada uygulayıcı olarak özel eğitim öğretmeninin (ör. Greene \& Bethune, 2021; Collins vd., 2017; Tekin-İftar \& Olcay-Gül, 2017); dört araştırmada yardımcı öğretmenin (Britton vd., 2017; Heinrich vd., 2016; Johnson vd., 2015; Riesen vd., 2003); üç araştırmada akran öğreticinin (Britton vd., 2017; Heinrich vd., 2016, Jimenez vd., 2012); dört araştırmada araştırmacının kendisinin (Jimenez vd., 2009; McMahon vd., 2015; Rivera vd., 2017; Sazak-Pınar \& Merdan, 2016); bir araştırmada sınıf öğretmeninin (Johnson vd., 2015) ve bir araştırmada ise bir araştırma görevlisinin (Knight vd., 2013) uygulayıcı olarak görev yaptığı tespit edilmiştir.

\section{Ortam ile İlgili Bulgular}

Çalışmaya dâhil edilen araştırmalar analiz edildiğinde hepsinde uygulamanın yapıldığı ortama ilişkin bilgilerin yer aldığı görülmüştür. Buna göre yedi araştırmanın özel eğitim sınıfında (ör. Jimenez vd., 2009; Rivera vd., 2017; Tekin-İftar \& Olcay-Gül, 2017); beş araştırmanın genel eğitim sınıfında (ör. Heinrich vd., 2016; Johnson vd., 2015; Riesen vd., 2003); beş kaynak odada (destek özel eğitim sınıfi) araştırmanın (ör. Britton vd., 2017; Collins vd., 2011; Karl vd., 2013); bir araştırmanın okul bahçesinde (Collins vd., 2017); bir araştırmanın 
bilgisayar laboratuvarında (McMahon vd., 2015), bir araştırmanın öğretmenler odasında (Smith vd., 2013) ve bir araştırmanın ise bireysel eğitim sınıfında (Sazak-Pınar \& Merdan, 2016) gerçekleştirildiği belirlenmiştir. Collins ve diğerleri (2007) tarafından gerçekleştirilen araştırma kaynak oda ve genel eğitim sınıfında; Heinrich ve diğerleri (2016) tarafından gerçekleştirilen araştırma ise özel eğitim sınıfı ve genel eğitim sınıfında gerçekleştirildiğinden birden fazla ortam grubuna dâhil edilmiştir.

\section{Araştırma Modeli ile İlgili Bulgular}

Bu çalışmaya dâhil edilen araştırmaların sekizinin davranışlar arası çoklu yoklama modeli (ör. Karl vd., 2013; McMahon vd., 2015; Smith vd., 2013); sekizinin katılımcılar arası çoklu yoklama modeli (ör. Collins vd., 2017; Heinrich vd., 2016; Rivera vd., 2017); ikisinin uyarlamalı dönüşümlü uygulamalar modeli (Collins vd., 2007; Riesen vd., 2003) kullanılarak desenlendiği tespit edilmiştir. Bir araştırma ise davranışlar arası çoklu başlama modeli ile tasarlanmıştır (Johnson vd., 2015).

\section{Bağımlı Değişkenler ile İlgili Bulgular}

Çalışmaya dâhil edilen araştırmalarda fen bilimleri dersine yönelik farklı ünitelere ait kazanımların öğretiminin hedeflendiği görülmüştür. Araştırmalarda, "Kuvvet ve enerji" (Greene \& Bethune, 2021; Jimenez vd., 2012; Karl vd., 2013); “Enerji dönüşümleri ve çevre kirliliği”" (Britton vd., 2017; Collins vd., 2017; Heinrich vd., 2016); "Canlılar dünyası" (Johnson vd., 2015; Rivera vd., 2017); "Vücudumuzdaki sistemler" (McMahaon vd., 2015; Tekin-İftar \& Olcay-Gül, 2017); "Sindirim" (Sazak-Pınar \& Merdan, 2016); "Canlılarda üreme, büyüme ve gelişme" (Jimenez vd., 2014; Smith vd., 2013); "Madde ve Isı" (Knight vd., 2013), "DNA ve genetik kod" (Riggs vd., 2013); "Saf madde ve karışımlar" (Collins vd., 2011); "Madde ve değişim" (Jimenez vd., 2009), "Elektrik iletimi" (Collins vd., 2007) ve "Yer kabuğu ve Dünya'nın hareketleri” (Riesen vd., 2003) ünitelerine ilişkin kazanımların öğretiminin hedeflendiği tespit edilmiştir.

\section{Bağımsız Değişken (Uygulama) ile İlgili Bulgular}

ÖGÖ’lere fen bilimleri konularının ve kavramlarının öğretiminde uygulanan yanlışsız öğretim yöntem türleri incelendiğinde, beş araştırmada sabit bekleme süreli öğretim (ör. Greene \& Bethune, 2021; Riggs vd., 2013; Smith vd., 2013); dört araştırmada eş zamanlı ipucu ile öğretim (ör. Britton vd., 2017; Karl vd., 2013; Tekin-İftar \& Olcay-Gül, 2017); üç araştırmada gömülü öğretim ile sabit bekleme süreli öğretim (Johnson vd., 2015; Jimenez vd., 2014; Jimenez vd., 2012); iki araştırmada grafik düzenleyici ile sabit bekleme süreli öğretim (Knight vd., 2013; Sazak-Pınar \& Merdan, 2016); bir araştırmada gömülü öğretim ile eş zamanlı ipucu ile öğretim (Heinrich vd., 2016); bir araştırmada teknoloji destekli sunulan öykü ile eş zamanlı ipucu ile öğretim (Rivera vd., 2017) ve bir araştırmada ise artırılmış gerçeklik uygulaması ile sabit bekleme süreli öğretim yönteminin (McMahaon vd., 2015) kullanıldığı belirlenmiş̧ir. Araştırmaların birinde gömülü öğretim yaklaşımıyla eş zamanlı ipucunun dağınık denemelerle ve ardıșık denemelerle sunumu karșılaştırılırken (Collins vd., 2007); diğer bir karșılaştırma araştırmasında ise gömülü öğretim yaklaşımıyla sunulan eş zamanlı ipucu ile öğretim ve sabit bekleme süreli öğretim yöntemleri (Riesen vd., 2003) karşılaştırıllmıştır.

\section{Veri Toplama Aracı ve Verilerin Analizi ile İlgili Bulgular}

Çalışmaya dâhil edilen bazı araştırmalarda veri toplama aracı doğrudan belirtilmediğinden veri toplama süreci göz önünde bulundurularak kullanılan veri toplama aracına karar verilmiştir. Buna göre 11 araştırmada ayrık deneme kaydı (ör. Britton vd., 2017; Greene \& Bethune, 2021; Rivera vd., 2017); dört araştırmada beceri analizi kaydı (Collins vd., 2017; Jimenez vd., 2009; Knight vd., 2013; Smith vd., 2013) ve iki araştırmada ise kalıcı ürün kaydı (Jimenez vd., 2014; Karl vd., 2013) veri toplama aracı olarak kullanılmıştır. Araştırmaların tamamında bağımsız değişkenin etkililiğinin görsel analiz yoluyla değerlendirildiği tespit edilmiştir.

\section{Uygulamanın Güvenirliği ile İlgili Bulgular}

\section{Uygulama Güvenirliği}

Analize dâhil edilen 16 araştırmada tüm oturumların en az \%10.5'inde (ranj $=10.5-100)$ uygulama güvenirliği verisi toplanmıştır. Üç araştırmada ise uygulama güvenirliği toplanmasına karşın oturumların ne kadarında güvenirlik verisi toplandığı ile ilgili bilgi verilmemiştir (Britton vd., 2017; Collins vd., 2007; Jimenez vd., 2012). Uygulama güvenirliği katsayısının \%81-\%100 arasında olduğu görülmüsşür. 


\section{Gözlemciler Arası Güvenirlik}

Bu çalışmada incelenen 16 araştırmada tüm oturumların en az \%20'sinde (ranj= 20-100) gözlemciler arası güvenirlik verisi toplanmıştır. Üç araştırmada ise gözlemciler arası güvenirlik verisi toplanmasına karşın oturumların ne kadarında güvenirlik verisi toplandığı ile ilgili bilgi verilmemiştir (Britton vd., 2017; Collins vd., 2007; Jimenez vd., 2012). Gözlemciler arası güvenirlik katsayısının \%66-\%100 arasında olduğu görülmüştür.

\section{Uygulamanın Etkililiği}

Çalışmaya dâhil edilen 19 araştırmanın tamamında, kullanılan bağımsız değişken(ler)in tüm katılımcılara hedeflenen becerileri/davranışları kazandırmada $\% 100$ oranında etkili olduğu tespit edilmiştir. Başka bir ifadeyle çalışmaya dâhil edilen araştırmalarda yer alan katılımcıların tamamının araştırmada belirlenen ölçütleri karşıladığı belirlenmiştir.

\section{Sosyal Geçerlik}

Çalışmaya dâhil edilen 12 araştırmada sosyal geçerlilik verisinin toplandığı, yedi araştırmada ise sosyal geçerlilik verisinin toplanmadığı (ör. Britton vd., 2017; Karl vd., 2013; Knight vd., 2013) belirlenmiş̧tir. Sosyal geçerlik verisi toplanan araştırmalar incelendiğinde üç araştırmada özel eğitim öğretmeni ve yardımc1 öğretmenden (Greene \& Bethune, 2021; Johnson vd., 2015; Rivera vd., 2017); üç araştırmada ÖGÖ'lerden (Collins vd., 2017; McMahon vd., 2015; Tekin-İftar \& Olcay-Gül, 2017); iki araştırmada akran öğretici ve ÖGÖ'den (Jimenez vd., 2012; Heinrich vd., 2016); iki araştırmada özel eğitim öğretmeninden (Jimenez vd., 2014; Sazak-Pınar \& Merdan, 2016); bir araştırmada özel eğitim öğretmeni ve ÖGÖ'den (Smith vd., 2013) ve bir araştırmada ise özel eğitim öğretmeni, sınıf öğretmeni ve ÖGÖ'den (Jimenez vd., 2009) sosyal geçerlik verisi toplandığı görülmüştür. Çalışmaya dâhil edilen araştırmaların tamamında sosyal geçerlik verileri öznel değerlendirme yoluyla toplanmıştır.

\section{İzleme/Kalıcılık ile İlgili Bulgular}

Ulaşılan araştırmaların 17'sinde izleme/kalıcılık verisinin toplandığı, iki araştırmada (McMahon vd., 2015; Riesen vd., 2003) ise izleme/kalıcılık verisinin toplanmadığ 1 tespit edilmiştir. İzleme/kalıcılık verisi toplanan araştırmalar incelendiğinde beş araştırmada ölçüt karşılandıktan hemen sonra (ör. Collins vd., 2011; Greene \& Bethune, 2021; Johnson vd., 2015), diğer araştırmalarda ise en az iki gün (ranj = 2 gün-8 hafta) sonra (ör. Collins vd., 2007; Sazak-Pınar \& Merdan, 2016; Tekin-İftar \& Olcay-Gül, 2017) izleme/kalıcılık verilerin toplandığı belirlenmiştir.

\section{Genelleme ile İlgili Bulgular}

Çalışmaya dâhil edilen 10 araştırmada genelleme verisinin toplandığı, diğer dokuz araştırmada (ör. Greene \& Bethune, 2021; Johnson vd., 2015; Smith vd., 2013) ise genelleme verisinin toplanmadığı belirlenmiştir. Genelleme verisi toplanan araştırmalar incelendiğinde beş araştırmada materyaller arası (ör. Collins vd., 2011; Jimenez vd., 2012; Riggs vd., 2013); iki araştırmada materyaller ve ortamlar arası (Jimenez vd., 2009; Karl vd., 2013); bir araştırmada ortamlar ve kişiler arası (Sazak-Pınar \& Merdan, 2016); bir araştırmada ortamlar arası (Heinrich vd., 2016) ve diğer bir araştırmada ise davranışlar arası (Tekin-İftar \& Olcay-Gül, 2017) genelleme verisinin toplandığ tespit edilmiştir. 
ÖZEL GEREKSINIMIMLİ ÖĞRENCILERE FEN BILIMLERİ ÖĞRETIMINDE

Tablo 1

Araştırmaya Dâhil Edilen Araştırmaların Betimsel Analiz Bulguları

\begin{tabular}{|c|c|c|c|c|c|c|c|c|c|c|c|c|c|c|}
\hline 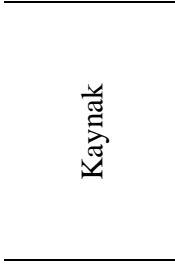 & 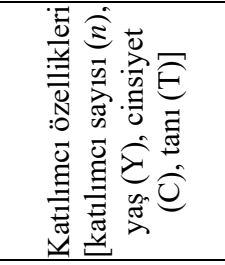 & 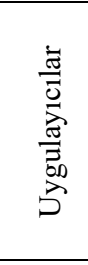 & 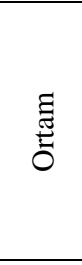 & 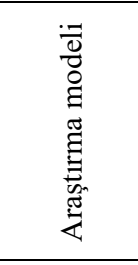 & 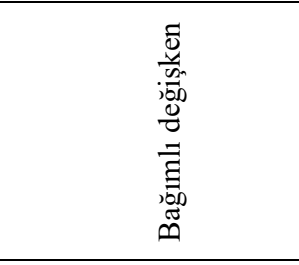 & 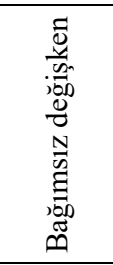 & 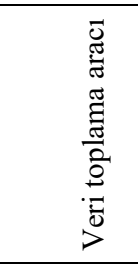 & 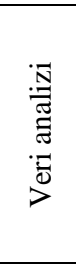 & 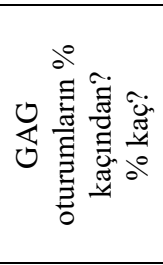 & 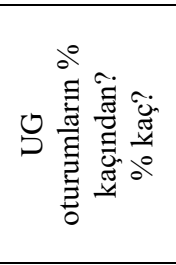 & 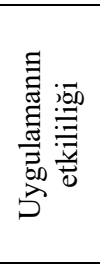 & 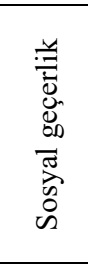 & 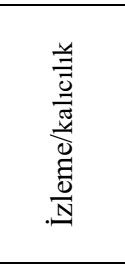 & 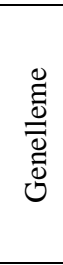 \\
\hline $\begin{array}{l}\text { Greene \& } \\
\text { Bethune, } \\
(2021)^{\mathrm{a}}\end{array}$ & $\begin{array}{c}n=3 \\
\mathrm{Y}: 7-9-10 \\
\text { C: } 3 \mathrm{E} \\
\mathrm{T}: \mathrm{ZY}+\mathrm{OSB}\end{array}$ & $\begin{array}{l}\text { ÖEÖ } \\
\text { Araş. }\end{array}$ & ÖES & DAÇYM & $\begin{array}{l}\text { Enerji, hava durumu ve } \\
\text { bitki anatomisi }\end{array}$ & SBSÖ & $\begin{array}{l}\text { Ayrık } \\
\text { deneme } \\
\text { kaydı }\end{array}$ & GA & $\begin{array}{c}\mathrm{E} \\
\% 21-25 \\
\% 96-100\end{array}$ & $\begin{array}{c}\mathrm{E} \\
\% 10.5 \\
\% 100\end{array}$ & $3 / 3$ & $\begin{array}{c}+ \\
\text { ÖEÖ } \\
\text { YÖ }\end{array}$ & ÖKS & - \\
\hline $\begin{array}{l}\text { Britton vd., } \\
\text { (2017) }\end{array}$ & $\begin{array}{l}n=1 \\
\text { Y: } 16 \\
\text { C: } 1 \mathrm{E} \\
\text { T: ZY }\end{array}$ & $\begin{array}{l}\text { AÖ } \\
\text { YÖ }\end{array}$ & $\mathrm{KO}$ & DAÇYM & $\begin{array}{l}\text { Çevre kirliliğgi ve geri } \\
\text { dönüşümle ilgili } \\
\text { kavramlar }\end{array}$ & EZî̈Ö & $\begin{array}{l}\text { Ayrik } \\
\text { deneme } \\
\text { kaydı }\end{array}$ & GA & $\begin{array}{c}\mathrm{E} \\
- \\
\% 66-100\end{array}$ & $\begin{array}{c}\mathrm{E} \\
- \\
\% 82-96\end{array}$ & $1 / 1$ & - & 2 hafta & - \\
\hline $\begin{array}{l}\text { Collins vd., } \\
\text { (2017) }\end{array}$ & $\begin{array}{c}n=4 \\
\text { Y: } 16-17-18-19 \\
\text { C: } 2 \mathrm{~K}, 2 \mathrm{E} \\
\text { T: ZY }\end{array}$ & ÖEÖ & OB & KAÇYM & $\begin{array}{l}\text { Bitki bakımı ve } \\
\text { fotosentez }\end{array}$ & EZiÖ & $\begin{array}{l}\text { Beceri } \\
\text { analizi } \\
\text { kaydı }\end{array}$ & GA & $\begin{array}{c}\mathrm{E} \\
\% 32-34 \\
\% 97-100\end{array}$ & $\begin{array}{c}\mathrm{E} \\
\% 32-33 \\
\% 100\end{array}$ & $4 / 4$ & $\stackrel{+}{+}$ & 8 hafta & - \\
\hline $\begin{array}{l}\text { Rivera vd., } \\
\text { (2017) }\end{array}$ & $\begin{array}{c}n=3 \\
\text { Y: } 6-6-8 \\
\text { C: } 1 \mathrm{~K}-2 \mathrm{E} \\
\text { T: GG(2)/ZY(1) }\end{array}$ & Araş. & ÖES & KAÇYM & Bitkinin kısımları & $\begin{array}{l}\text { TDSÖ+ } \\
\text { EZIIOO }\end{array}$ & $\begin{array}{l}\text { Ayrık } \\
\text { deneme } \\
\text { kaydı }\end{array}$ & GA & $\begin{array}{c}\mathrm{E} \\
\% 100 \\
\% 96-100\end{array}$ & $\begin{array}{c}\mathrm{E} \\
\% 40 \\
\% 100\end{array}$ & $3 / 3$ & $\begin{array}{c}+ \\
\text { ÖEÖ } \\
\text { YÖ }\end{array}$ & 4 hafta & $\stackrel{+}{\mathrm{MA}}$ \\
\hline $\begin{array}{l}\text { Tekin-İftar \& } \\
\text { Olcay-Gül, } \\
\text { (2017) }\end{array}$ & $\begin{array}{c}n=3 \\
\text { Y: } 10-11-11 \\
\text { C: } 3 \mathrm{E} \\
\text { T: OSB }\end{array}$ & ÖEÖ & ÖES & DAÇYM & $\begin{array}{l}\text { Organların işlevleri ve } \\
\text { vücudumuzdaki yeri }\end{array}$ & EZİ̈Ö & $\begin{array}{l}\text { Ayrik } \\
\text { deneme } \\
\text { kaydı }\end{array}$ & GA & $\begin{array}{c}\mathrm{E} \\
\% 30 \\
\% 100\end{array}$ & $\begin{array}{c}\mathrm{E} \\
\% 33 \\
\% 87-100\end{array}$ & $3 / 3$ & $\stackrel{+}{+}$ & 10 gün & $\begin{array}{c}+ \\
\mathrm{DA}\end{array}$ \\
\hline $\begin{array}{l}\text { Heinrich vd., } \\
\text { (2016) }\end{array}$ & $\begin{array}{l}n=3 \\
\text { Y: } 16-17-17 \\
\text { C: } 1 \mathrm{~K}, 2 \mathrm{E} \\
\mathrm{T}: \mathrm{ZY}\end{array}$ & $\begin{array}{l}\text { AÖ } \\
\text { YÖ }\end{array}$ & $\begin{array}{l}\text { ÖES } \\
\text { GES }\end{array}$ & KAÇYM & $\begin{array}{l}\text { Taşıma kapasitesi, } \\
\text { kaynaklar, ekosistem, } \\
\text { türler, sınırlayıcı } \\
\text { faktörler }\end{array}$ & $\begin{array}{l}\text { GÖ+ } \\
\text { EZiÖ }\end{array}$ & $\begin{array}{l}\text { Ayrik } \\
\text { deneme } \\
\text { kaydı }\end{array}$ & GA & $\begin{array}{c}\mathrm{E} \\
\% 20-50 \\
\% 100\end{array}$ & $\begin{array}{c}\mathrm{E} \\
\% 20-50 \\
\% 83-100\end{array}$ & $3 / 3$ & $\begin{array}{c}+ \\
\text { AÖ } \\
\text { ÖGÖ }\end{array}$ & 1 ay & $\stackrel{+}{\mathrm{OA}}$ \\
\hline $\begin{array}{l}\text { Sazak-Pınar } \\
\text { \& Merdan, } \\
\text { (2016) }\end{array}$ & $\begin{array}{c}n=3 \\
\text { Y: } 10-10-11 \\
\text { C: } 1 \mathrm{~K}, 2 \mathrm{E} \\
\text { T: OSB }\end{array}$ & Araş. & BES & KAÇYM & Sindirim & $\begin{array}{l}\text { GD+ } \\
\text { SBSÖ }\end{array}$ & $\begin{array}{l}\text { Ayrik } \\
\text { deneme } \\
\text { kaydı }\end{array}$ & GA & $\begin{array}{c}\mathrm{E} \\
\% 30 \\
\% 98\end{array}$ & $\begin{array}{c}\mathrm{E} \\
\% 30 \\
\% 96-\% 98\end{array}$ & $3 / 3$ & $\begin{array}{l}+ \\
\stackrel{+}{O E O ̈}\end{array}$ & 1-3 hafta & $\begin{array}{c}+ \\
\text { OA } \\
\text { KA }\end{array}$ \\
\hline
\end{tabular}


Tablo 1 (devami)

\begin{tabular}{|c|c|c|c|c|c|c|c|c|c|c|c|c|c|c|}
\hline 坣 & 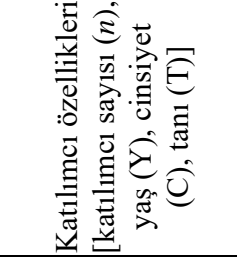 & 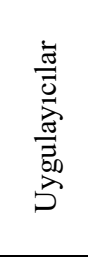 & Е & 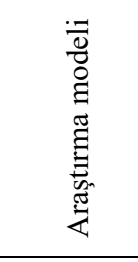 & 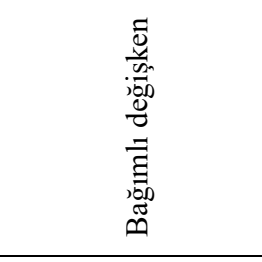 & 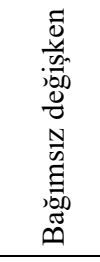 & 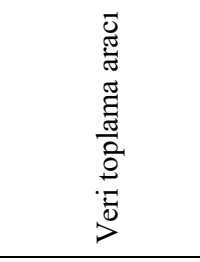 & 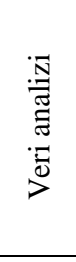 & 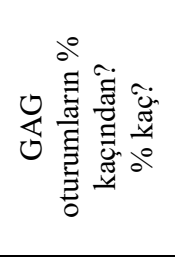 & 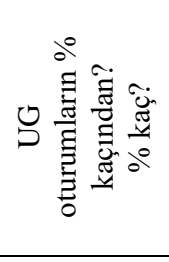 & 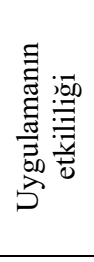 & 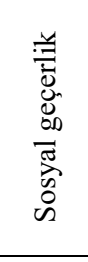 & 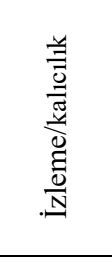 & 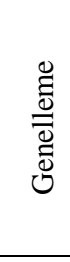 \\
\hline $\begin{array}{l}\text { Johnson vd., } \\
\text { (2015) }\end{array}$ & $\begin{array}{c}n=3 \\
\mathrm{Y}: 7-8-9 \\
\mathrm{C}: 2 \mathrm{~K}, 1 \mathrm{E} \\
\mathrm{T}: \mathrm{ZY}(2) / \mathrm{OSB}\end{array}$ & $\begin{array}{l}\text { SÖ } \\
\text { YÖ }\end{array}$ & GES & DAÇBM & $\begin{array}{l}\text { Bitkiler, böcekler } \\
\text { ve örümcekler, } \\
\text { anatomi }\end{array}$ & $\begin{array}{l}\text { GÖ+ } \\
\text { SBSÖ }\end{array}$ & $\begin{array}{l}\text { Ayrık deneme } \\
\text { kaydı }\end{array}$ & GA & $\begin{array}{c}E \\
\% 66 \\
\% 97-100\end{array}$ & $\begin{array}{c}\mathrm{E} \\
\% 100 \\
\% 90-100\end{array}$ & $3 / 3$ & $\begin{array}{l}+ \\
\text { ÖEÖ } \\
\text { YÖ }\end{array}$ & ÖKS & - \\
\hline $\begin{array}{l}\text { McMahon vd., } \\
\text { (2015) }\end{array}$ & $\begin{array}{c}n=4 \\
\text { Y:19-20-25-25 } \\
\text { C: } 3 \mathrm{~K}, 1 \mathrm{E} \\
\text { T: ZY(3)/OSB }\end{array}$ & Araş. & BL & DAÇYM & $\begin{array}{l}\text { Kemikler, organlar } \\
\text { ve hücre }\end{array}$ & $\begin{array}{l}\text { AGU+ } \\
\text { SBSÖ }\end{array}$ & Kelime testi & GA & $\begin{array}{c}\mathrm{E} \\
\% 60 \\
\% 90-100\end{array}$ & $\begin{array}{c}\mathrm{E} \\
\% 60 \\
\% 92-100\end{array}$ & $3 / 3$ & $\stackrel{++}{\stackrel{+}{O}}$ & - & - \\
\hline $\begin{array}{l}\text { Jimenez vd., } \\
\text { (2014) }\end{array}$ & $\begin{array}{c}n=3 \\
\mathrm{Y}: 9 \\
\mathrm{C}: 1 \mathrm{~K}, 2 \mathrm{E} \\
\mathrm{T}: \mathrm{ZY}+\mathrm{OSB}\end{array}$ & ÖEÖ & ÖES & DAÇYM & $\begin{array}{l}\text { Kayaç döngüsü, } \\
\text { yaşam döngüsü ve } \\
\text { duyular ünitesi } \\
\text { sınav puanları }\end{array}$ & $\begin{array}{l}\text { GÖ+ } \\
\text { SBSÖ }\end{array}$ & $\begin{array}{l}\text { Kalıcı ürün } \\
\text { kaydı }\end{array}$ & GA & $\begin{array}{c}\mathrm{E} \\
\% 33 \\
\% 100\end{array}$ & $\begin{array}{c}\mathrm{E} \\
\% 39 \\
\% 97\end{array}$ & $3 / 3$ & $\stackrel{+}{\stackrel{+}{O E O ̈ ~}}$ & 1 hafta & - \\
\hline Karl vd., (2013) & $\begin{array}{c}n=4 \\
\mathrm{Y}: 15-15-16-18 \\
\mathrm{C}: 1 \mathrm{~K}, 3 \mathrm{E} \\
\mathrm{T}: \mathrm{ZY}\end{array}$ & ÖEÖ & KO & DAÇYM & Kuvvet kavramı & EZİ̈Ö & $\begin{array}{l}\text { Kalıcı ürün } \\
\text { kaydı }\end{array}$ & GA & $\begin{array}{c}\mathrm{E} \\
\% 26-33 \\
\% 100\end{array}$ & $\begin{array}{c}\mathrm{E} \\
\% 26-33 \\
\% 100\end{array}$ & $4 / 4$ & - & $\begin{array}{l}1-3-5 \\
\text { hafta }\end{array}$ & $\begin{array}{c}+ \\
\text { MA } \\
\text { OA }\end{array}$ \\
\hline $\begin{array}{l}\text { Knight vd., } \\
\text { (2013) }\end{array}$ & $\begin{array}{c}n=3 \\
\mathrm{Y}: 13-14-14 \\
\mathrm{C}: 1 \mathrm{~K}, 2 \mathrm{E} \\
\mathrm{T}: \mathrm{ZY}+\mathrm{OSB}\end{array}$ & As. & $\mathrm{KO}$ & KAÇYM & $\begin{array}{l}\text { Konveksiyon } \\
\text { kavramı }\end{array}$ & $\begin{array}{l}\text { GD+ } \\
\text { SBSÖ }\end{array}$ & $\begin{array}{l}\text { Beceri analizi } \\
\text { kaydı }\end{array}$ & GA & $\begin{array}{c}\mathrm{E} \\
\% 25 \\
\% 98.9-100\end{array}$ & $\begin{array}{c}\mathrm{E} \\
\% 25 \\
\% 100\end{array}$ & $3 / 3$ & - & 1 hafta & $\stackrel{+}{\mathrm{MA}}$ \\
\hline $\begin{array}{l}\text { Riggs vd., } \\
\text { (2013) }\end{array}$ & $\begin{array}{c}n=5 \\
\text { Y: } 14-15-16-16-18 \\
\text { C: } 2 \mathrm{~K}, 3 \mathrm{E} \\
\mathrm{T}: \mathrm{ZY}\end{array}$ & ÖEÖ & ÖES & KAÇYM & Kalıtım ilkeleri & SBSÖ & $\begin{array}{l}\text { Ayrık deneme } \\
\text { kaydı }\end{array}$ & GA & $\begin{array}{c}\mathrm{E} \\
\% 31.1 \\
\% 100\end{array}$ & $\begin{array}{c}\mathrm{E} \\
\% 100 \\
\% 99\end{array}$ & $5 / 5$ & - & $\begin{array}{c}1-3 \\
\text { hafta }\end{array}$ & $\stackrel{+}{\mathrm{MA}}$ \\
\hline $\begin{array}{l}\text { Smith vd., } \\
\text { (2013) }\end{array}$ & $\begin{array}{c}n=3 \\
\mathrm{Y}: 6-7-7 \\
\mathrm{C}: 2 \mathrm{~K}, 1 \mathrm{E} \\
\mathrm{T}: \mathrm{ZY}(1) / C ̧ \mathrm{Y}(2) \\
\end{array}$ & ÖEÖ & ÖO & DAÇYM & Yaşam döngüsü & SBSÖ & $\begin{array}{l}\text { Beceri analizi } \\
\text { kaydı }\end{array}$ & GA & $\begin{array}{c}\mathrm{E} \\
\% 30-45 \\
\% 92-100\end{array}$ & $\begin{array}{c}\mathrm{E} \\
\% 30-45 \\
\% 100\end{array}$ & $3 / 3$ & $\begin{array}{l}\stackrel{+}{+} \\
\text { ÖEÖ } \\
\text { ÖGÖ }\end{array}$ & 5 hafta & - \\
\hline
\end{tabular}


Tablo 1 (devami)

\begin{tabular}{|c|c|c|c|c|c|c|c|c|c|c|c|c|c|c|}
\hline 莺 & 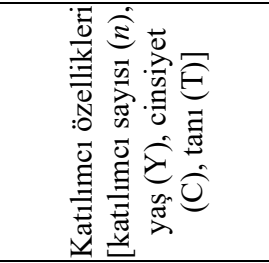 & 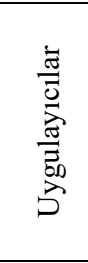 & Е & 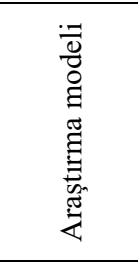 & 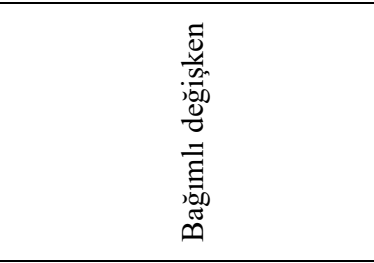 & 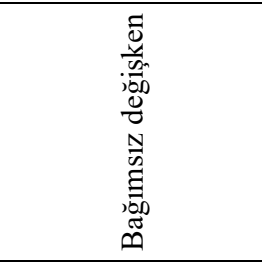 & 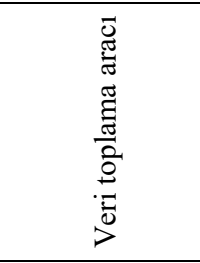 & 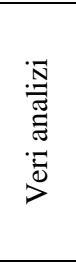 & 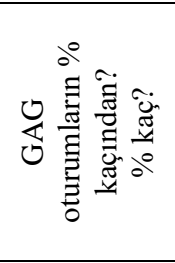 & 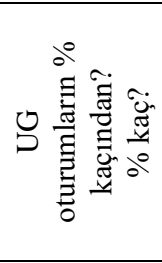 & 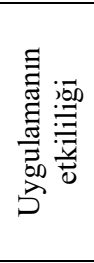 & 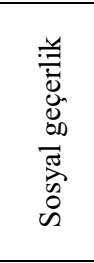 & 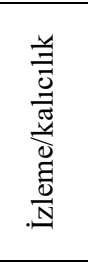 & 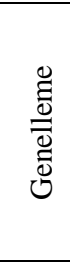 \\
\hline $\begin{array}{l}\text { Jimenez vd., } \\
(2012)\end{array}$ & $\begin{array}{c}n=5 \\
\mathrm{Y}: 11-11-11-13-14 \\
\text { C: } 2 \mathrm{~K}, 3 \mathrm{E} \\
\mathrm{T}: \mathrm{ZY}\end{array}$ & AÖ & GES & KAÇYM & $\begin{array}{l}\text { Teknoloji, potansiyel ve } \\
\text { kinetik enerji, tektonik } \\
\text { hareketler }\end{array}$ & $\begin{array}{l}\text { GÖ+ } \\
\text { SBSÖ }\end{array}$ & $\begin{array}{l}\text { Kalıcı ürün } \\
\text { kaydı }\end{array}$ & GA & $\begin{array}{c}\mathrm{E} \\
- \\
\% 100\end{array}$ & $\begin{array}{c}\mathrm{E} \\
- \\
\% 96.3\end{array}$ & $5 / 5$ & $\begin{array}{c}\stackrel{+}{+} \text { ÖGÖ } \\
\text { AÖ }\end{array}$ & ÖKS & $\stackrel{+}{\mathrm{MA}}$ \\
\hline $\begin{array}{l}\text { Collins vd., } \\
\text { (2011) }\end{array}$ & $\begin{array}{c}n=3 \\
\mathrm{Y}: 14 \\
\mathrm{C}: 1 \mathrm{~K}, 2 \mathrm{E} \\
\mathrm{T}: \mathrm{ZY}(2) / \mathrm{OSB}(1)\end{array}$ & ÖEÖ & $\mathrm{KO}$ & DAÇYM & Elementler ve bileşikler & SBSÖ & $\begin{array}{l}\text { Ayrık deneme } \\
\text { kaydı }\end{array}$ & GA & $\begin{array}{c}\mathrm{E} \\
\% 32.9 \\
\% 95-100\end{array}$ & $\begin{array}{c}\mathrm{E} \\
\% 32.9 \\
\% 81-100\end{array}$ & $3 / 3$ & - & ÖKS & $\stackrel{+}{\mathrm{MA}}$ \\
\hline $\begin{array}{l}\text { Jimenez vd., } \\
(2009)\end{array}$ & $\begin{array}{c}n=3 \\
\mathrm{Y}: 11-12-13 \\
\mathrm{C}: 2 \mathrm{~K}, 1 \mathrm{E} \\
\mathrm{T}: \mathrm{ZY}\end{array}$ & Araş. & ÖES & KAÇYM & $\begin{array}{l}\text { Kimyasal reaksiyonlar ve } \\
\text { hal değişimi }\end{array}$ & SBSÖ & $\begin{array}{l}\text { Beceri analizi } \\
\text { kaydı }\end{array}$ & GA & $\begin{array}{c}\mathrm{E} \\
\% 25 \\
\% 100\end{array}$ & $\begin{array}{c}\mathrm{E} \\
\% 25 \\
\% 100\end{array}$ & $3 / 3$ & $\begin{array}{l}+ \\
\stackrel{+}{\text { ÖEÖ }} \\
\text { SÖ } \\
\text { ÖGÖ }\end{array}$ & ÖKS & $\begin{array}{c}+ \\
\mathrm{MA} \\
\mathrm{OA}\end{array}$ \\
\hline $\begin{array}{l}\text { Collins vd., } \\
(2007)\end{array}$ & $\begin{array}{c}n=4 \\
\text { Y: } 9-13-13-19 \\
\text { C: } 1 \mathrm{~K}, 3 \mathrm{E} \\
\text { T: ZY }\end{array}$ & ÖEÖ & $\begin{array}{l}\text { KO } \\
\text { GES }\end{array}$ & UDUM & $\begin{array}{l}\text { Titreşim, elektrik ve } \\
\text { yoğunlaşma kavramları }\end{array}$ & $\begin{array}{c}\text { GÖ+ } \\
\text { EZİ̈̈ } \\
\text { (Ardışık deneme X } \\
\text { Dağınık deneme) }\end{array}$ & $\begin{array}{l}\text { Ayrık deneme } \\
\text { kaydı }\end{array}$ & GA & $\begin{array}{c}\mathrm{E} \\
- \\
\% 100\end{array}$ & $\begin{array}{c}\mathrm{E} \\
- \\
\% 97-100\end{array}$ & $4 / 4$ & - & $\begin{array}{l}2 \\
\text { gün }\end{array}$ & - \\
\hline $\begin{array}{l}\text { Riesen vd., } \\
\text { (2003) }\end{array}$ & $\begin{array}{c}n=4 \\
\text { Y: } 13-13-14-14 \\
\text { C: } 1 \mathrm{~K}, 3 \mathrm{E} \\
\text { T: OSB, ÇY(2), ZY }\end{array}$ & YÖ & GES & UDUM & $\begin{array}{l}\text { Gezegenler, fosiller, 1sı } \\
\text { iletimi, kıtalar, radyasyon, } \\
\text { yer kabuğu, jeoloji, kütle, } \\
\text { yer çekimi, hal değişimleri }\end{array}$ & $\begin{array}{c}\text { GÖ+ } \\
\text { SBSÖ } \\
\text { X } \\
\text { GÖ+ } \\
\text { EZİÖ }\end{array}$ & $\begin{array}{l}\text { Ayrık deneme } \\
\text { kaydı }\end{array}$ & GA & $\begin{array}{c}\mathrm{E} \\
\% 72.2-85.7 \\
\% 100\end{array}$ & $\begin{array}{c}\mathrm{E} \\
\% 28.1 \\
\% 99-100\end{array}$ & $4 / 4$ & - & - & - \\
\hline
\end{tabular}

${ }^{a}$ Tarama yapıldığında, 2019 yılında erken görünümde olan bu çalıșmanın güncel yayım tarihi 2022'dir.

Not: İncelenen araştırmalar güncel tarihten geriye doğru bir sıra izleyerek verilmiştir. Araş = araştırmacı; AÖ = akran öğretici; BES = bireysel eğitim sınıfi; ÇY = çoklu yetersizlik; DAÇYM = davranışlar arası çoklu yoklama modeli; $\mathrm{E}$ = erkek; $\mathrm{E}$ = Evet; GA = görsel analiz; $\mathrm{GD}$ = grafik düzenleyici; $\mathrm{GES}$ = genel eğitim sınıfi; $\mathrm{GG}$ = gelişimsel gerilik; GÖ = gömülü ögretim; H = hayır; K = kadın; KA = kişiler arası; KAÇYM = katılımcılar arası çoklu yoklama modeli; $\mathrm{KO}=$ kaynak oda; $\mathrm{MA}=$ materyaller arası; $\mathrm{OA}=$ ortamlar arası; $\mathrm{OB}=$ okul bahçesi; OSB = otizm spektrum bozukluğu; ÖEÖ = özel eğitim öğretmeni; ÖES = özel eğitim sınıfi; ÖGÖ = özel gereksinimli öğrenci; ÖKS = ölçüt karşılandıktan sonra; ÖO = öğretmen odası; SBSÖ = sabit bekleme süreli öğretim; UDUM = uyarlamalı dönüşümlü uygulamalar modeli; YÖ = yardımcı öğretmen; ZY = zihin yetersizliği. 


\section{Tartışma}

ÖGÖ’lere fen bilimleri konularının ve kavramlarının öğretiminde yanlışsız öğretim yöntemlerinin uygulandığ 1 ve tek-denekli araştırma modellerinin kullanıldığ ulusal ve uluslararası 19 araştırma belirlenen değişkenler açısından incelenerek betimsel olarak analiz edilmiştir. Çalışmaya 19 araş̧ırma dahil edilmiştir ancak bunların sadece ikisi ulusal çalışmadır. Bu anlamda yapılan bu çalışma ile her tür ve düzeyde yetersizliğge sahip ÖGÇ'lere fen bilimleri gibi akademik becerilerin öğretimi konusunda yanlışsız öğretim yöntemlerinin uygulandığı ve tek-denekli araştırma modellerinin kullanıldığı ulusal çalışmaların sayısının artması beklenmektedir. Çalışmanın bulguları, ÖGÖ’lere fen bilimleri konularının ve kavramlarının öğretiminde, öğretimi gerçekleștirilen konuların kalıcilığının ve genellemesinin sağlanmasında yanlışsız öğretim yöntemlerinin etkili olduğunu ortaya koymaktadır. Çalışmadan elde edilen bulgular mevcut sistematik derleme çalışmaları (ör. Apanasionok vd., 2019; Spooner vd., 2011; Spooner vd., 2012; Taylor vd., 2019) bulgularıyla da benzerlik göstermektedir. Spooner ve diğerleri (2012) tarafından gerçekleştirilen sistematik derleme çalışmasında, ÖGÖ’lere fen bilimleri konularının öğretiminde bekleme süreli öğretimin kanıt temelli bir uygulama olduğu belirlenmiştir. Bu derleme çalışmasından elde edilen bulgular, Spooner ve diğerlerinin (2012) çalışmasından elde edilen derleme bulgularını desteklemektedir.

Çalışmanın bulgularına göre, araştırmalarda 6-25 yaş aralığında toplam 64 katılımcının yer aldığı ve bu katılımcıların tamamına yakınını ZY ve OSB olan çocukların oluşturduğu belirlenmiştir. Geriye kalan öğrencilerin ise çoklu yetersizlik ve gelişimsel gerilik tanıları vardır. Bu bulgu, farklı yetersizliği olan ÖGÖ’lere etkililiği kanıtlanmış öğretim yöntemleri sunulduğunda üst düzey akademik bir beceri olan fen bilimleri konularını ve kavramlarını ögrenebilecekleri bulgusunu desteklemektedir (Spooner vd., 2011; Spooner vd., 2012; Taylor vd., 2019). Katılımcıların sınıf düzeyleri incelendiğinde ise büyük çoğunluğunun ilköğretim çağındaki öğrenciler olduğu görülmektedir. Bu bulgu, Therrien ve diğerleri (2011) tarafından gerçekleştirilen sistematik derleme çalışmasının bulgularından farklılık göstermektedir. Therrien ve diğerlerinin (2011) yapmış oldukları sistematik derleme çalışmasında, analize dâhil edilen çalışmalarda yer alan katılımcıların tamamına yakınını ortaokul çağındaki öğrenciler oluşturmaktadır. Çünkü Therrien ve diğerleri (2011) yapmış oldukları derleme çalışmasına dahil ettikleri araştırmalarda katılımcıların okul çağındaki (6-12 yaş) ÖÖG olan çocukların olması ölçütünü dikkate almıştır. Dolayısıyla, bu çalışma katılımcıların daha geniş yaş aralığında olmasıyla mevcut alanyazından farklılaşmakta ve diğer araştırmanın bulgularını genişletmektedir. Katılımcıların cinsiyetlerine ilişkin bulgular incelendiğinde 40'nin erkek ve 24'nün kız öğrenci olduğu görülmektedir. Katılımcıların cinsiyetlerine ilişkin bu bulgu, Therrien ve diğerleri (2011) tarafından gerçekleştirilen sistematik derleme çalışması bulgularıyla tutarlık göstermektedir. Çalışmaya dâhil edilen araştırmaların katılımcı özellikleri incelendiğinde, yetersizlik düzeyi orta ve üzerinde olan çocuklara üst düzey akademik becerilerin öğretildiği görülmektedir. Dolayısıyla bu çalışma bulguları yetersizlik düzeyi orta ve üzerinde olan çocuklara üst düzey akademik becerilerin öğretilmesi ile ilgili ulusal düzeyde araştırmalara gereksinim duyulduğunu göstermektedir çünkü ulusal çalışma sayısı oldukça sinırlidir.

Araştırmaların uygulayıcılara ilişkin betimsel analiz bulguları incelendiğinde ise araştırmaların tamamına yakınında uygulayıcıların öğretmenler olduğu görülmektedir. Öğretmen uygulayıcıların sayılarının fazla olması, yanlışsı öğretim yöntemlerinin öğretmenler tarafindan sınıflarda kolaylıkla kullanılabileceğini göstermektedir. Araştırmaların uygulama süreçleri incelendiğinde, uygulayıcılara bağımsız değişkene ilişkin özel bir eğitimin verilmediği görülmüş̧ür. Bu durum da diğer ülkelerde öğretmenlerin yanlışsı öğretim yöntemlerini kolaylıkla sınıflarında uyguladığını gösterebilir. Buna ek olarak alanyazında yer alan diğer sistematik derleme (Apanasionok vd., 2019; Spooner vd., 2011; Spooner vd., 2012; Taylor vd., 2019) çalışmalarında uygulayıcı bilgilerine yer verilmediği, dolayısıyla bu çalışmada uygulayıcılara ilişkin elde edilen bulguların mevcut özellikle ulusal alanyazına katkı sağlayacağı düşünülebilir. Şöyle ki tek-denekli araştırmalarda ülkemizde çoğunlukla araştırmacılar rol almaktadır (Sazak-Pınar \& Merdan, 2016) ancak öğretmenlere gerekli eğitim verilerek araştırmalarda daha fazla rol almaları sağlanabilir ve böylece öğretmenlerin kanıt temelli uygulamalar konusunda farkındalığı ve yetkinliği artmış olur.

Çalışmaya dâhil edilen araştırmalar ortam özellikleri açısından da incelenmiştir çünkü tek-denekli araştırma modellerinde, uygulamanın tekrarlanabilirliği açısında yapıldığı ortamın betimlenmesi oldukça önemlidir. Araştırmalarda uygulamaların yürütüldüğ̈̈ ortamlar incelendiğinde, uygulamaların büyük çoğunluğunun genel eğitim okullarında gerçekleştirildiği görülmektedir. ÖGÖ’lerin akademik alanlarda desteklenmeleri onların tipik gelişim gösteren akranlarıyla aynı ortamlarda eğitim alma olanaklarını artırmaktadır (Riesen vd., 2003). Spooner ve diğerleri (2011) tarafından gerçekleştirilen sistematik derleme çalışmasında, 
derlemeye dâhil edilen araştırmaların katılımcılarının büyük çoğunluğu genel eğitim sınıfına devam eden orta ve ağır düzeyde yetersizliği olan öğrencilerken; Spooner ve diğerleri (2012) tarafından gerçekleştirilen çalışmada, katılımcıların tamamı ağır düzeyde yetersizliği olan öğrencilerdir. Bu bağlamda çalışmadan elde edilen bu bulgular, mevcut sistematik derleme çalışmalarının bulgularını destekler niteliktedir. Özellikle uluslararası araştırmaların gerçekleştiği ortamlar incelendiğinde yetersizlik düzeylerinin orta ve üzerinde olmasına rağmen ÖGÖ'lerin akranlarıyla genel eğitim okullarında eğitim aldıkları görülmüştür. Bu durum ilgili araştırmaların yapıldığı ortamlarda bütünleştirme uygulamalarının oldukça yaygın olduğu anlamına gelebilir. Bu çalışmanın bulgularından yola çıkarak, ülkemizde kaynaştırma/bütünleştirme ortamlarında eğitim alan ÖGÖ’lerin yetersizlik düzeyleri ile BEP'lerinde yer alan akademik beceriler karşılaştırılarak ÖGÖ’lerin eğitim programları gözden geçirilebilir.

Alanyazında özel eğitimde fen bilimleri öğretimi ile ilgili çalışmalar hakkında yapılan sistematik derlemeler incelendiğinde çoğunlukla yöntem ve bağımsız değişken konusunda bir sınırlamaya gidilmediği, genel olarak taramanın yapıldığı görülmüş̧ür. Bu çalışmada ise özel eğitim alanında yaygın olarak kullanılan tek-denekli araştırma modelleri ile yapılmış olan araştırmalar dâhil edilmiştir. Nitekim geçmişten günümüze özel eğitim alanında yapılan araştırmalar incelendiğinde yoğunlukla tek-denekli araştırma modellerinin yaygın bir şekilde uygulandığı görülmektedir. Bu durumun en önemli nedeni, ÖGÖ’lerin her birinin farklı gelişim özelliklerine sahip olmaları olarak belirtilebilir. Araştırmalar, araştırma modelleri açısından incelendiğinde 19 çalışmanın tamamına yakınında yanlışsız öğretim yöntemlerinin etkililiğini sınamak için tek-denekli araştırma modellerinden çoklu yoklama ve çoklu başlama desenlerinin kullanıldığ görülmektedir. Bununla birlikte bir çalışmada eş zamanlı ipucuyla öğretim yönteminin gömülü öğretim yöntemiyle birlikte ardışık ve dağınık denemelerle sunulmasının etkililiklerini karşılaştırmak ve bir çalışmada ise eş zamanlı ipucuyla öğretim ve sabit bekleme süreli öğretim yöntemlerinin gömülü öğretim yöntemiyle sunulmasının etkililiğini karş̧laştırmak üzere uyarlamalı dönüşümlü uygulamalar modeli kullanılmıştır. Bu bulgu Apanasionok ve diğerleri (2019) tarafından gerçekleştirilen sistematik derleme çalışmasının bulgularıyla tutarlık göstermektedir. Ülkemizde orta ve ağır derece yetersizliğe sahip öğrencilere çoğunlukla öz bakım ve toplumsal yaşam becerilerinin çalışıldığı düşünülürse bu çalışma, yanlışsı öğretim yöntemleri ile bu tür öğrencilere akademik becerilerin de kazandırılabileceğini düşündürmektedir. Bu çalışmanın bulguları yanlışsı öğretim yöntemleri ve bu yöntemlerin sistematik bir şekilde uygulanması durumunda orta ve ağır derece yetersizliğe sahip ÖGÖ’lerin akademik bir beceri olan fen öğretimi konusunda olumlu çıktılar elde edildiğini göstermektedir. Bu durumun özellikle ulusal düzeyde bir farklılık oluşturması beklenmektedir çünkü orta ve ağır derece yetersizliğe sahip ÖGÖ’lerle fen bilgisi gibi akademik beceri öğretimlerinin yapıldığı ulusal çalışma sayısı oldukça sınırlıdır (Sazak-Pınar \& Merdan, 2016; Tekin-İftar \& Olcay-Gül, 2017).

Çalışmaya dâhil edilen araştırmaların bağımlı ve bağımsız değişkenleri incelendiğinde, yoğunlukla fizik, kimya ve biyoloji gibi fen bilimleri alanlarında yer alan konuların öğretiminin hedeflendiği görülmektedir. Bu konuların öğretiminde en sık kullanılan yanlışsı öğretim yöntemi, sabit bekleme süreli öğretim ve eş zamanlı ipucuyla öğretim yöntemidir. Ayrıca, her iki yanlışsız öğretim yönteminin teknoloji desteğiyle, grafik düzenleyicilerle ve artırılmış gerçeklik uygulamalarıyla sunulduğunda da etkili olduğu belirlenmiştir. Özellikle sabit bekleme süreli ve eş zamanlı ipucuyla öğretim yöntemlerinin doğal öğretim yaklaşımlarından olan gömülü öğretimle sunulduğunda da etkili olduğu görülmektedir. Araştırmanın bağımlı ve bağımsız değişkenlere ilişkin bu bulgusu, Apanasionok ve diğerleri (2019), Spooner ve diğerleri (2011) ve Spooner ve diğerleri (2012) tarafindan gerçekleştirilen sistematik derleme çalışmalarının bulgularıyla tutarlık göstermektedir. Ulaşılan araştırmalar incelendiğinde, araştırmacıların bağımlı değişkene yönelik olarak yanlışsız öğretim yöntemine ek olarak farklı bir yöntem de uyguladıkları görülmüştür. Bu anlamda günlük rutinler, etkinlik ya da geçişler arasında uygun firsatlar oluşturulması durumunda da fen bilimleri konularının ÖGÖ'lere öğretilebileceği söylenebilir. Bu araştırmalarda yöntemlerinin etkililiğinin karşılaştırıldığı çalışmalar da mevcuttur. Bu tarz uygulamalar ülkemizde yaygınlaştırılabilir. Dolayısıyla bu araştırma bulgularından yola çıkarak genelleme ve kalıcılı̆̆ın artırılması için yanlışsı öğretim yöntemlerinin doğal öğretim yöntemleriyle birleştirilerek uygulandığ (ör. Gömülü öğretim) araştırmalar planlanarak etkililik bakılabilir.

Araştırmaların güvenirliğe ilişkin betimsel analiz bulguları incelendiğinde, gözlemciler arası güvenirlik ve uygulama güvenirliği katsayılarının yüksek olduğu görülmektedir. Analize dâhil edilen tüm araştırmalarda her iki güvenirlik verisinin toplanmış olması ve güvenirlik katsayılarının yüksek olmasının rapor edilen verilerin ne denli güvenilir olduğunu göstermesi açısından önemli olduğu düşünülmektedir. Alanyazında yer alan Horner ve diğerleri (2005), tek-denekli araştırma modellerinin kalite göstergelerini yedi ana başlıkta incelemektedir ve araştırma güvenirlik verilerinin oldukça önemli olduğunu ve \%80'in altında olmaması gerektiğini 
vurgulamaktadır. $\mathrm{Bu}$ anlamda araştırmalarda bilimsel uygulama basamaklarının titizlikle takip edildiği düşünülebilir. Fen bilimleri konu ve kavramlarının öğretiminde yanlışsız öğretim yöntemlerinin uygulandığı ve tek-denekli araştırma modellerinin kullanıldığı araştırmaları konu edinen mevcut alanyazında yer alan diğer sistematik derleme çalışmalarında analize dâhil edilen araştırmaların güvenirlik verilerine ilişkin analiz gerçekleştirilmemiş̧ir. Dolayısıyla bu çalışmada analize dahil edilen araştırmalar geçerlik ve güvenirlik verileri açısından incelendiğginden, çalışmadan elde edilen bulguların alanyazına katkı sağlayacağı düşünülmektedir.

Derlemeye dâhil edilen araştırmalar etkililik bulguları açısından incelendiğinde, araştırmalarda yer alan tüm katılımcıların hedeflenen becerileri/davranışları edindiklerini göstermektedir. Yanlışsız öğretim yöntemlerinin, ÖGÖ’lere fen konularının ve kavramlarının öğretiminde etkili olduğunu ortaya koyan diğer sistematik derleme (ör. Apanasionok vd., 2019; Spooner vd., 2011; Spooner vd., 2012; Taylor vd., 2019) bulgularıyla tutarlık göstermekte olup, örneklendirilen sistematik derlemelerde de yanlış öğretim yöntemlerinin ÖGÖ’lere fen konularının ve kavramlarının öğretiminde etkili olduğu bulgularına ulaşıılmıştır. İzleme verisine ilişkin betimsel analiz bulguları ise izleme verisi toplanan çalışmalarda, ÖGÖ’lerin edindikleri becerileri öğretim sona erdikten sonra da koruduklarını ortaya koymaktadır. Benzer şekilde genellemeye ilişkin betimsel analiz bulguları, ÖGÖ’lerin edindikleri fen bilimleri konularını ve kavramlarını farklı materyallere, ortamlara, kişilere ve davranışlara genelleyebildiklerini göstermektedir. Mevcut derleme çalışmaları incelendiğinde, izleme ve genelemeye ilişkin betimsel analiz bulgularına yer verilmediği görülmektedir. $\mathrm{Bu}$ anlamda bu çalışmadan elde edilen izleme ve genellemeye ilişkin betimsel analiz bulgularının mevcut alanyazına katkı sağlayacağı düşünülmektedir.

Ulaşılan araştırmalarda betimsel analize dâhil edilen diğer bir değişken sosyal geçerlik verisidir. Araştırmaların önemli bir kısmında sosyal geçerlik verisinin toplandığ 1 görülmektedir. Sosyal geçerlik verisi toplanan araştırmalarda, öğretmenler, akran öğreticiler ve çalışmada yer alan ÖGÖ’ler çalışmalara ilişkin olumlu görüş bildirmişlerdir. Sosyal geçerlik verisi toplanan araştırmalarda, aile üyelerinin çalışmalara ilişkin görüşlerinin alınmadığı belirlenmiştir. Alanyazında yer alan sistematik derleme çalışmalarında analize dâhil edilen çalışmaların sosyal geçerlik bulgularına iliş̧in analizlerin yapılmamış olması sebebiyle bu araştırma bulgularının alanyazına katkı sağlayacağı düşünülmektedir.

Bu bulgular doğrultusunda mevcut sistematik derleme çalışmasının birtakım sınırlılıkları bulunmaktadır. Bunlardan birincisi, derleme sürecine dâhil edilen araştırmalar yöntemsel kaliteleri (Horner vd., 2005) ve desen standartları (Kratochwill vd., 2013) gibi özellikler açısından detaylı bir değerlendirme süzgecinden geçirilmemiş̧ir. İkincisi ise araştırmaya sadece hakemli dergilerde yayımlanmış çalışmaların dâhil edilmiş olması ve lisansüstü tezlerin dâhil edilmemiş olmasıdır. Kimi zaman lisansüstü tez çalışmaları farklı sebeplerden (araştırmacı özellikleri, uygulamanın etkili olmaması vb.) kaynaklı olarak yayımlan(a)mamaktadır (Kıyak vd., 2019). Son olarak, bu araştırma ÖGÖ'lere fen bilimleri konularının ve kavramlarının öğretiminde yanlışsız öğretim yöntemlerinin uygulandığı, ulusal ve uluslararası tek-denekli araştırma modelleri ile sınırlıdır.

\section{Sonuç}

Bu çalışmadan elde edilen bulgular, yanlışsız öğretim yöntemlerinin farklı yetersizlik türü, sınıf düzeyi ve yaş grubundaki ÖGÖ’lere fen bilimleri konularının ve kavramlarının öğretiminde etkili olduğunu göstermektedir. Bu bulgular, konu ile ilgili yürütülmüş önceki sistematik derleme bulgularıyla tutarlık göstermekte ve yukarıda söz edilen bazı noktalar açısından da mevcut alanyazını zenginleştireceği düşünülmektedir. Sonuç olarak, öğretmenlerin yanlışsız öğretim yöntemlerini sınıf ortamlarında kullanarak ÖGÖ’lere üst düzey akademik bir beceri olan fen bilimleri konularının ve kavramlarının öğretebileceği görülmektedir.

\section{Öneriler}

Bulgulardan hareketle, bağımlı ve bağımsız değişkene ilişkin bulgular, ÖGÖ’lere uygun destek sunulduğunda ve doğru öğretim yöntemlerinin tercih edilmesi durumunda bu bireylerin kimya, biyoloji ve fizik gibi fen bilimleri alanlarına ilişkin becerileri edinebileceklerini göstermektedir. Bu nedenle, öğretmenlere ÖGÖ’lere fen bilimleri konularının öğretiminde yanlışsız öğretim yöntemlerinin kullanımı önerilebilir. Bu nedenle, öğretmenlerin hizmet içi eğitim programı içeriklerine yanlışsı öğretim yöntemleri de dâhil edilebilir. Araştırmacılar, bağımsız değişken uygulayıcıları olarak öğretmenlerin rol aldığı araştırmalar planlayabilir. Buna ek olarak, hangi yanlışsız öğretim yönteminin fen konu ve kavramlarının öğretiminde daha etkili ve verimli olduğunu belirlemek için çalışmalar planlanabilir. Son olarak, ÖGÖ’lere fen bilimleri konularının öğretiminde hangi öğretim yöntemlerinin kullanıldığını belirlemek üzere sistematik derleme çalışmaları yürütülebilir. Son 
olarak, fen bilimleri konularının öğretimi için yanlış öğretim yöntemlerinin uygulandığı ve tek denekli araştırma modellerinin incelendiği meta-analiz çalışmaları planlanabilir.

\section{Yazarların Katkı Düzeyleri}

Bu araştırma bir ders bağlamında hazırlanmıştır. Yazarlar birlikte konuyu belirlemiştir. Daha sonra birinci yazar, ikinci yazarın yönergeleri kapsamında taramayı ve verilerin analizini gerçekleştirmiştir. İkinci yazar araştırmanın güvenirlik çalışmalarını yapmıştır ve birinci yazarın tüm çalışmalarını adım adım takip etmiştir. Araşıtırmaya dahil edilen çalışmaların çoğu İngilizce olduğu için çalışmalar ikinci yazar tarafından dil açısından da kontrol edilmiştir. Makalenin İngilizce yazımı da ikinci yazara aittir. Her iki yazar daha sonra araştırmanın yazımını yapmıştır. İkinci yazar ayrıca araştırmanın yayınından sorumlu yazar olup, tüm yazışmaları yürütmüştür. 


\section{Kaynaklar}

*Betimsel analize dâhil edilen çalıșmalar.

Apanasionok, M. M., Hastings, R. P., Grindle, C. F., Watkins, R. C., \& Paris, A. (2019). Teaching science skills and knowledge to students with developmental disabilities: A systematic review. Journal of Research in Science Teaching, 56(7), 847-880. https://doi.org/10.1002/tea.21531

*Britton, N. S., Collins, B. C., Ault, M. J., \& Bausch, M. E. (2017). Using a constant time delay procedure to teach support personnel to use a simultaneous prompting procedure. Focus on Autism and Other Developmental Disabilities, 32(2), 102-113. https://doi.org/10.1177/1088357615587505

Caseau, D., \& Norman, K. (1997). Special education teachers use science-technology-society (STS) themes to teach science to students with learning disabilities. Journal of Science Teacher Education, 8(1), 55-68. https://doi.org/10.1023/A:1009453403131

Clements, D. H., \& Sarama, J. (2016). Math, science, and technology in the early grades. The Future of Children, 26(2), 75-94. https://www.jstor.org/stable/43940582

*Collins, B. C., Evans, A., Creech-Galloway, C., Karl, J., \& Miller, A. (2007). Comparison of the acquisition and maintenance of teaching functional and core content sight words in special and general education settings. Focus on Autism and Other Developmental Disabilities, 22(4), 220-233. http://dx.doi.org/10.1177/10883576070220040401

*Collins, B. C., Hager, K. L., \& Galloway, C. C. (2011). Addition of functional content during core content instruction with students with moderate disabilities. Education and Training in Autism and Developmental Disabilities, 46(1), 22-39. https://www.jstor.org/stable/23880028

*Collins, B. C., Terrell, M., \& Test, D. W. (2017). Using a simultaneous prompting procedure to embed core content when teaching a potential employment skill. Career Development and Transition for Exceptional Individuals, 40(1), 36-44. https://doi.org/10.1177/2165143416680347

Çapraz, C. (2016). Ortaokul özel alt sınıfta öğrenim gören zihinsel yetersizliğe sahip ögrencilere bazı maddelerin "katı, sıvı ve gaz" hallerinin doğrudan ögretim yöntemiyle ögretimi [Teaching the "solid, liquid and gas" states of some substances by direct instruction teaching method to students with intellectual disabilities] (Tez Numarası: 433815) [Doktora tezi, Atatürk Üniversitesi]. Yükseköğretim Kurulu Ulusal Tez Merkezi.

Dağseven, D. (2001). Zihinsel engelli öğrencilere, temel toplama ve saat okuma becerilerinin kazandırılmasl, sürekliliği ve genellenebilirliğinde, doğrudan ve basamaklandırılmış ögretim yaklaşımlarına göre hazırlanan ögretim materyallerinin farklılaşan etkililiği [The differentiating effectiveness of teaching materials prepared according to direct and stratified teaching approaches in the provision, continuity and generalizability of basic collection and time reading skills to students with intellectual disabilities] (Tez Numarası: 108833) [Yüksek lisans tezi, Gazi Üniversitesi]. Yükseköğretim Kurulu Ulusal Tez Merkezi.

Dedeoğlu, S., Durali, S., \& Tanrıverdi-Kış, A. (2004). Özel eğitim bölümü zihin engelliler öğretmenliği anabilim dalı 3., 4. sınıf öğrencileri ve mezunlarının kendi bölüm programları, öğretmen yetiştirme ve eğitim fakülteleri ile ilgili düşünce ve önerileri [The thoughts and suggestions of the 3rd and 4th undergraduates students and graduated students of the Special Education Department about special education programs, teacher training and education faculties]. Ankara Üniversitesi Ĕgitim Bilimleri Fakültesi Özel Ĕgitim Dergisi, 5(1), 47-55. https://doi.org/10.1501/Ozlegt_0000000074

Denizli, H. (2015). Fen bilimleri dersi öğretmenlerinin ve fen bilimleri dersini alan kaynaştırma öğrencilerinin kaynaştırma eğitimi uygulamaları sürecine ilişkin görüş ve önerileri [Opinions and suggestions of science class teachers and students with disabilities taking science class on the application process of inclusion practices] (Tez Numarası: 415476) [Yüksek lisans tezi, Giresun Üniversitesi]. Yükseköğretim Kurulu Ulusal Tez Merkezi.

Gersten, R., Fuchs, L. S., Compton, D., Coyne, M., Greenwood, C., \& Innocenti, M. S. (2005). Quality indicators for group experimental and quasi-experimental research in special education. Exceptional Children, 71(2), 149-164. https://doi.org/10.1177/001440290507100202 
*Greene, A., \& Bethune, K. S. (2021). The effects of systematic instruction in a group format to teach science to students with autism and intellectual disability. Journal of Behavioral Education, 30(1), 62-79. https://doi.org/10.1007/s10864-019-09353-6

*Heinrich, S., Collins, B. C., Knight, V., \& Spriggs, A. D. (2016). Embedded simultaneous prompting procedure to teach STEM content to high school students with moderate disabilities in an inclusive setting. Education and Training in Autism and Developmental Disabilities, 51(1), 41-54. https://www.jstor.org/stable/10.2307/26420363

Horner, R. H., Carr, E. G., Halle, J., McGee, G., Odom, S., \& Wolery, M. (2005). The use of single-subject research to identify evidence-based practice in special education. Exceptional Children, 71(2), 165-179. https://doi.org/10.1177/001440290507100203

*Jimenez, B. A., Browder, D. M., \& Courtade, G. R. (2009). An exploratory study of self-directed science concept learning by students with moderate intellectual disabilities. Research and Practice for Persons with Severe Disabilities, 34(2), 33-46. https://doi.org/10.2511/rpsd.34.2.33

*Jimenez, B. A., Browder, D. M., Spooner, F., \& Dibiase, W. (2012). Inclusive inquiry science using peermediated embedded instruction for students with moderate intellectual disability. Exceptional Children, 78(3), 301-317. http://dx.doi.org/10.1177/001440291207800303

*Jimenez, B. A., Lo, Y. Y., \& Saunders, A. F. (2014). The additive effects of scripted lessons plus guided notes on science quiz scores of students with intellectual disability and autism. The Journal of Special Education, 47(4), 231-244. http://dx.doi.org/10.1177/0022466912437937

*Johnson, J. W., McDonnell, J., Holzwarth, V. N., \& Hunter, K. (2015). The efficacy of embedded instruction for students with developmental disabilities enrolled in general education classes. Journal of Positive Behavior Interventions, 6(4), 214-227. https://doi.org/10.1177/10983007040060040301

Karaçam, Z. (2013). Sistematik derleme metodolojisi: Sistematik derleme hazırlamak için bir rehber [Systematic review methodology: A guide to preparing systematic reviews]. Dokuz Eylül Üniversitesi Hemşirelik Fakültesi Elektronik Dergisi, 6(1), 26-33. https://dergipark.org.tr/en/pub/deuhfed/issue/46815/587078

*Karl, J., Collins, B. C., Hager, K. D., \& Ault, M. J. (2013). Teaching core content embedded in a functional activity to students with moderate intellectual disability using a simultaneous prompting procedure. Education and Training in Autism and Developmental Disabilities, 48(3), 363-378. https://www.jstor.org/stable/23880993

Knight, V. F., Spooner, F., Browder, D. M., Smith, B. R., \& Wood, C. L. (2013). Using systematic instruction and graphic organizers to teach science concepts to students with autism spectrum disorders and intellectual disability. Focus on Autism and Other Developmental Disabilities, 28(2), 115-126. http://dx.doi.org/10.1177/1088357612475301

Kıyak, Ü. E., Tuna, D. M., \& Tekin-İftar, E. (2019). Zihin yetersizliği olan bireylere güvenlik becerilerinin öğretimi: Kapsamlı betimsel analiz [Teaching safety skills to individuals with intellectual disabilities: Comprehensive descriptive analysis]. Ankara Üniversitesi Eğitim Bilimleri Fakültesi Özel Eğitim Dergisi, 20(1), 143-176. http://dx.doi.org/10.21565/ozelegitimdergisi.408927

Kratochwill, T. R., Hitchcock, J. H., Horner, R. H., Levin, J. R., Odom, S. L., Rindskopf, D. M., \& Shadish, W. R. (2013). Single-case intervention research design standards. Remedial and Special Education, 34(1), 26-38. https://doi.org/10.1177/0741932512452794

Lynch, S., Taymans, J., Watson, W. A., Ochsendorf, R. J., Pyke, C., \& Szesze, M. J. (2007). Effectiveness of a highly rated science curriculum unit for students with disabilities in general education classrooms. Exceptional Children, 73(2), 202-223. https://doi.org/10.1177/001440290707300205

*McMahon, D. D., Cihak, D. F., Wright, R. E., \& Bell, S. M. (2015). Augmented reality for teaching science vocabulary to postsecondary education students with intellectual disabilities and autism. Journal of Research on Technology in Education, 48(1), 38-56. http://dx.doi.org/10.1080/15391523.2015.1103149

Melekoğlu, M. (2017). Erken çocuklukta okul çaplı olumlu davranış desteği modelinin etkililiği [The effectiveness of school-wide positive behavior support model in early childhood]. (Tez Numaras1: 463439) [Doktora tezi, Anadolu Üniversitesi]. Yükseköğretim Kurulu Ulusal Tez Merkezi. 
Mete, P. (2016). Ortaokul özel alt sinıfta öğrenim gören zihinsel yetersizliğe sahip ögrrencilere bazı maddelerin "sert-yumuşak" özelliklerinin doğrudan ögretim yöntemiyle ögrretimi [Teaching the "hard-soft" properties of some items by direct teaching method to students with intellectual disabilities studying in a special education classroom of a secondary school] (Tez Numarası: 442999) [Doktora tezi, Atatürk Üniversitesi]. Yükseköğretim Kurulu Ulusal Tez Merkezi.

Mete, P., Çapraz, C., \& Yıldırım, A. (2017). Zihinsel yetersizliğe sahip öğrenciler için fen eğitimi [Science education for students with disabilities]. Journal of Graduate School of Social Sciences, 21(1), 289-304. https://dergipark.org.tr/tr/pub/ataunisosbil/issue/35347/425793

Milli Eğitim Bakanlığı [Ministry of National Education]. (2005). Illköğretim fen ve teknoloji dersi (4 ve 5. sinıflar) ögretim programı [Primary school science and technology classes (4th and 5th grades) curriculum]. http://mufredat.meb.gov.tr/ProgramDetay.aspx?PID=325

Milli Eğitim Bakanlığı [Ministry of National Education]. (2018). Özel Eğitim Hizmetleri Yönetmeliği [Special education services regulation]. T.C. Resmi Gazete (30471), 07 Temmuz 2018, 22-56.

Milli Eğitim Bakanlı̆̆ı [Ministry of National Education]. (2020). Özel eğitim hizmetleri genel müdürlü̆̈̆ [General directorate of special education and guidance services]. https://orgm.meb.gov.tr/meb_iys dosyalar/2021_09/13143029 TURKYYEYDE_OZEL_EYYTYM_H YZMETLERY.pdf

Okçu, B., \& Sözbilir, M. (2017). Görme yetersizliği olan öğrencilere yönelik bir etkinlik tasarımı: Sigorta nedir? [An activity design for students with visually impaired: What is insurance?]. Journal of Inquiry Based Activities, 7(1), 42-50. http://efe.atauni.edu.tr/standartsite/assets/efedisiyayinlar/D.10.pdf

*Riesen, T., McDonnell, J., Johnson, J. W., Polychronis, S., \& Jameson, M. (2003). A comparison of constant time delay and simultaneous prompting within embedded instruction in general education classes with students with moderate to severe disabilities. Journal of Behavioral Education, 12(4), 241-259. https://doi.org/10.1023/A:1026076406656

*Riggs, L., Collins, B. C., Kleinert, H., \& Knight, V. F. (2013). Teaching principles of heredity to high school students with moderate and severe disabilities. Research and Practice for Persons with Severe Disabilities, 38(1), 30-43. https://doi.org/10.2511/027494813807046971

*Rivera, C. J., Hudson, M. E., Weiss, S. L., \& Zambone, A. (2017). Using a multicomponent multimedia shared story intervention with an iPad to teach content picture vocabulary to students with developmental disabilities. Education and Treatment of Children, 40(3), 327-352. https://www.researchgate.net/publication/320013819

Sazak-Pınar, E., \& Merdan, F., (2016). Grafik düzenleyicilerin otizmli öğrencilere fen bilgisi kavramlarının ögretimindeki etkililiği [The effectiveness of graphic organizers in teaching science concepts to students with autism spectrum disorder]. Ahi Evran Üniversitesi Kırşehir Eğitim Fakültesi Dergisi (KEFAD), 17(1), 111-131. https://kefad2.ahievran.edu.tr/archieve/pdfler/Cilt17Sayi1/JKEF_17_1_2016_111131.pdf

Scruggs, T. E., Mastropieri, M. A., \& Boon, R. (1998). Science education for students with disabilities: A review of recent research. Studies in Science Education, 32(1), 21-44. https://doi.org/10.1080/03057269808560126

Sinoplu, K. (2009). Zihinsel engellilerde matematik ögretimi [Teaching mathematics for students with disabilities] (Tez Numarası: 237249) [Yüksek lisans tezi, Selçuk Üniversitesi]. Yükseköğretim Kurulu Ulusal Tez Merkezi.

*Smith, B. R., Spooner, F., Jimenez, B. A., \& Browder, D. (2013). Using an early science curriculum to teach science vocabulary and concepts to students with severe developmental disabilities. Education and Treatment of Children, 36(1), 1-31. http://dx.doi.org/10.1353/etc.2013.0002

Spooner, F., Knight, V., Browder, D., Jimenez, B., \& DiBiase, W. (2011). Evaluating evidence-based practice in teaching science content to students with severe developmental disabilities. Research and Practice for Persons with Severe Disabilities, 36(1-2), 62-75. https://doi.org/10.2511/rpsd.36.1-2.62 
Spooner, F., Knight, V. F., Browder, D. M., \& Smith, B. R. (2012). Evidence-based practice for teaching academics to students with severe developmental disabilities. Remedial and Special Education, 33(6), 374-387. https://doi.org/10.1177/0741932511421634

Tarhan, R. (2019). Özel eğitim ögretmenlerinin zihin engelli öğrencilere yönelik fen eğitiminde karşılaşttkları sorunlar ve bu sorunların çeşitli değişkenler açısından incelenmesi [The problems faced by special education teachers in science education for students with intellectual disabilities and the examination of these problems in terms of various variables] (Tez Numarası: 573695) [Yüksek lisans tezi, Ağrı İbrahim Çeçen Üniversitesi]. Yükseköğretim Kurulu Ulusal Tez Merkezi.

Taylor, J. C., Rizzo, K. L., Hwang, J., \& Hill, D. (2019). A review of research on science instruction for students with autism spectrum disorder. School Science and Mathematics, 120(2), 116-125. https://doi.org/10.1111/ssm.12388

Tekin, E. (1999). Yanlışsı öğretim yöntemleri [Errorless teaching methods]. Özel Eğitim Dergisi, 2(3), 87-102. https://doi.org/10.1501/Ozlegt 0000000043

Tekin, E. (2000). Karşılaştırmalı tek-denekli araştırma modelleri [Comparative single-subject research models]. Özel Eğitim Dergisi, 2(4), 1-12. https://doi.org/10.1501/Ozlegt 0000000049

*Tekin-İftar, E., \& Olcay-Gül, S. (2017). Increasing instructional efficiency when using simultaneous prompting procedure in teaching academic skills to students with autism spectrum disorders. International Electronic Journal of Elementary Education, 9(2), 451-472.

Tekin-İftar, E., \& Kırcaali-İftar, G. (2012). Özel eğitimde yanlışslz ögrretim yöntemleri [Errorless teaching methods in special education]. Vize Yayınc1lik.

Therrien, W. J., Taylor, J. C., Hosp, J. L., Kaldenberg, E. R., \& Gorsh, J. (2011). Science instruction for students with learning disabilities: A meta-analysis. Learning Disabilities Research \& Practice, 26(4), 188-203. https://doi.org/10.1111/j.1540-5826.2011.00340.x

Villanueva, M. G., Taylor, J., Therrien, W., \& Hand, B. (2012). Science education for students with special needs. Studies in Science Education, 48(2), 187-215. https://doi.org/10.1080/14703297.2012.737117

Yorke-Servis, J. (2012). A comparison study on teacher-centered and inquiry-based instruction in science education of middle school students with learning disabilities: What is effective? [Unpublished doctoral dissertation]. Rowan University. https://rdw.rowan.edu/etd/231

Zawacki-Richter, O., Kerres, M., Bedenlier, S., Bond, M., \& Buntins, K. (Eds.). (2020). Systematic reviews in educational research: Methodology, perspectives and application. Springer.

Zorluoğlu, S., \& Sözbilir, M. (2017). Görme yetersizliği olan öğrencilerin öğrenmelerini destekleyici ihtiyaçlar [The needs that support the learning of students with visually impaired]. Trakya Üniversitesi Eğitim Fakültesi Dergisi, 7(2), 659-682. https://doi.org/10.24315/trkefd.279369 


\section{Ankara University Faculty of Educational Sciences Journal of Special Education}

2022, 23(2), 481-506
SYSTEMATIC REVIEW

Recieved Date: 29.10 .20

Accepted Date: 04.06.21

OnlineFirst: 18.06 .21

\title{
Errorless Teaching Methods in Teaching Science to Students with Disabilities: Systematic Review
}

\author{
Hicran Denizli-Gülboy iD 1
}

Meral Melekoğlu iD2

\begin{abstract}
Introduction: The use of effective teaching methods in special education is frequently emphasized in the literature. Errorless teaching methods are particularly effective in teaching academic skills. Similarly, errorless teaching methods are effective in science teaching. However, teachers mostly need knowledge and practice about effective teaching methods such as errorless teaching methods.
\end{abstract}

Method: In this study, the studies using the single-subject experimental research method in which errorless teaching methods are applied in science teaching to students with disabilities were examined in terms of certain variables with the descriptive analysis approach.

Findings: The research includes 19 studies published in national and international peer-reviewed journals between 2000 and 2020. The studies have been examined in some variables. It was found that the studies mostly used multiple baseline and multiple probe designs; 64 participants were included in the studies, and most of the participants had intellectual disability and autism spectrum disorder. In addition, constant time delay and simultaneous prompting teaching methods were used mostly.

Discussion: With this study, it is expected that the number of national studies may increase in which errorless teaching methods are applied and single-subject research models are used in the teaching of academic skills such as science to students with special needs.

Conclusion: It is seen that errorless teaching methods are quite effective in science teaching in special education.

Suggestions: The subject of effective methods can be added to teachers' in-service training programs. Studies on this issue can be increased in the national literature.

Keywords: Science teaching, special education, errorless teaching, single-subject design, autism, intellectual disability, science.

To cite: Denizli-Gülboy, H., \& Melekoğlu, M. (2022). Errorless teaching methods in teaching science to students with disabilities: Systematic review. Ankara University Faculty of Educational Sciences Journal of Special Education, 23(2), 481-506. https://doi.org/10.21565/ozelegitimdergisi.833253

${ }^{1}$ MS, Eskişehir Osmangazi University, Institute of Education, E-mail: hicrandnzl@ hotmail.com, https://orcid.org/0000-00016732-1536

${ }^{2}$ Corresponding Author: Assist. Prof., Eskişehir Osmangazi University, Education Faculty, Department of Special Education, E-mail: meralmelekoğlu@gmail.com, https://orcid.org/0000-0003-4349-9959 


\section{Introduction}

When the special education services for students with disabilities are evaluated from past to present, it is seen that there have been improvements in many areas such as legal regulations, regulations in educational settings, education programs, materials (Ministry of National Education [MoNE], 2018). However, nowadays most of the teachers are not aware of effective practices and have difficulties in including effective practices in instruction. Actually, effective practices are very important in teaching science subjects as in all skills. In the context of this importance, the Ministry of National Education stated that there are individual differences between students and it is necessary to create an appropriate learning environment for all students to be educated as science-literate individuals by paying attention to their individual differences. In addition to this, it was stated that these students need more time, practice, a learning process consisting of various materials and methods in order to gain the concepts and skills in the science class (MoNE, 2005).

In the literature, it is important to maintain a quality education life for the students with disabilities in accordance with their individual differences in order to be a science literate like their peers with typical development. For this, there is a need for some regulations and special teaching methods and also teachers should encourage the students with disabilities to develop a positive attitude towards the science course that contains information they can use in their daily lives (Dağseven, 2001; Denizli, 2015; Mete, 2016). Therefore, it is necessary to increase the competence of both special education and science teachers in applying effective teaching methods while presenting the curriculum determined for these students (Lynch et al., 2007). For this reason, it is necessary to determine the special education teaching methods used in science teaching.

When the literature is examined, Spooner et al. (2011) aimed to determine the evidence-based practices in teaching science subjects to students with moderate and severe disabilities in their systematic review study. The findings of the study revealed that errorless teaching methods are effective evidence-based practices in teaching science subjects to students with moderate and severe disabilities (Tekin-İftar \& Kurcaali-İftar, 2012). When the literature is examined, it is seen that a systematic review is needed to examine the frequency of implementation or the effectiveness of errorless teaching methods that are effective in teaching academic skills as in teaching many other skills to students with intellectual disability (ID) and autism spectrum disorder ASD).

The purpose of this study is to make a systematic review of studies using a single-subject experimental research method in which errorless teaching methods are applied in teaching science subjects and concepts to students with disabilities. In the study, 19 researches were examined by conducting descriptive analysis, in terms of demographic characteristics of participants, research models, setting and interventionists, dependent and independent variables, effectiveness of the implementations, data collection and analysis process, reliability, social validity, monitoring and generalization variables.

\section{Method}

\section{Research Model}

In this study, a systematic review was made to examine the studies conducted with single-subject experimental designs by using errorless teaching methods in the teaching of science subjects and concepts to students with disabilities in terms of certain variables (Karaçam, 2013; Zawacki-Richter et al., 2020). The studies included in this research in the context of certain criteria were analyzed with a descriptive analysis approach in terms of certain variables.

\section{Literature Search}

During the research process, a two-stage scanning process was followed in the process of determining the researches to be included in the research. Electronic scanning was carried out in the first stage and manual scanning was carried out in the second stage. In the electronic scanning process libraries of two public universities includes EbscoHost, ERIC, JSTOR, SAGE, Premier, Science Direct, Scopus, Springer, Taylor \& Francis, and Wiley databases and the Scientific and Technological Research Council of Turkish National Academic Network and Information Center (TUBITAK ULAKBIM) was searched using the keywords determined by researchers. In the manual scanning process, the references of the researches obtained from the electronic databases were examined and the studies considered to be relevant with the research topic were included in the research.

The scanning process was done by using the key words; Autis* or ASD or "Autism spectrum disorder*" or "Intellectual disabilit*" or ID or "Mental retardation" or "Developmental disabilit*" or "Down syndrome" or "Learning disabilit*" or "Learning difficult*" or "Learning impairment*" or "Intellectual deficien*" or 
"Developmental impairment*" or Handicap* and Scien* or Physics or Chemistry or Biology or Plant* or Animal* or "Human bod*" or Material* or Force* or Earth or Electricity or Acid* or Rocks or Soil or Magnet* or Space or Chemical or Weather or Season* or Mass or Planet* or "Solar system*" or "Living organism*" or Cell* or Bodypart* or Fungus or Insect* or Temperature or "Work* or scientifically" or "Scien* or Enquiry" or "Scien* or İnquiry" or "Scien* or Experiment" or STEM or "Scien* or Model* and analog* or "Scien* pattern-seek*" or "Scien* curriculum" or "Scien* intervention" or "Scien* program*" or "Scien* or Prediction" or "Scien* or Classification" or "Scien*". Thus, during the scanning process reached total 3593 studies and these studies were analyzed according to the inclusion criteria. At the end of the scanning process 19 studies were included in this research.

\section{Inclusion and Exclusion Criteria}

The inclusion criteria of this study are; (a) at least one of the participants in the research was diagnosed with disability, (b) the dependent variable was selected from the field of science, (c) the independent variable or at least one of the independent variable groups was one of the errorless teaching methods, (d) the study was conducted with single-subject experimental designs and (e) the study was published in a national or international peer-reviewed journals. The exclusion criteria of this research are; (a) the independent variable is one of the teaching methods other than at least one of the errorless teaching methods, (b) the research was carried out using a research design other than single-subject experimental designs, and (c) the reading comprehension studies in the texts related to science.

\section{Coding}

Before starting the research, the inclusion and exclusion criteria into the research were determined in the context of the purpose of the research. Since the studies included in the research would be analyzed with the descriptive analysis approach, a coding key sheet was created by considering the variables were mostly used in the systematic reviews and meta-analysis studies in the literature, the quality indicators of the single-subject research stated in Horner et al. (2005). In this coding key sheet; (a) research model, (b) setting, (c) participant characteristics (number of participants, age range, gender, diagnosis), (d) implementer, (e) dependent variable, (f) independent variable, $(\mathrm{g})$ data collection tool, (h) data analysis, (i) effectiveness of the implementations, (i) interobserver agreement, (j) fidelity of implementation, (k) social validity, (l) monitoring/maintenance and (m) generalization. All of the studies included in the study were read and the data were entered into the coding key sheet.

\section{Reliability}

Reliability analysis was conducted in two steps in $30 \%$ of the studies, which were randomly selected. During these analyses "Number of agreement between researchers / (Number of agreement + number of disagreement between researchers) X 100" formula was used. In the first step, 100\% agreement was obtained between the researchers with regard to inclusion and exclusion criteria. Subsequent reliability analysis was conducted to show whether the researchers coded the studies regarding demographical, procedural, and outcome parameters reliably and $98 \%$ agreement was found.

\section{Findings}

In this section, the findings obtained from the study are reported in order. The research includes 19 studies published in national and international peer-reviewed journals between 2000 and 2020. All studies that met the research inclusion criteria were analyzed with a descriptive analysis approach in the context of research questions and the findings obtained are included.

\section{Findings About Participants}

A total of 64 participants were included in the 19 studies included in this research, 40 of them male and 24 female students. Information regarding the ages of the participants was provided in all of the studies. The average age of the participants was determined to be 13.1 years (range $=6-25$ years). When the distribution of the studies according to age groups is analyzed, in 12 studies, the participants were in the 6-13 age range (e.g., Collins et al., 2007; Greene \& Bethune, 2021; Jimenez et al., 2012); In nine studies, participants were between the ages of 14-18 (e.g., Britton et al., 2017; Collins et al., 2011; Collins et al., 2017) and in three studies the participants were aged over 19 (Collins et al., 2007; Collins et al., 2017; McMahon et al., 2015). 
When the disability types of the participants in the studies were examined, it was found that 39 participants had intellectual and developmental disability (e.g., Britton et al., 2017; Collins et al., 2017; Jimenez et al., 2009); nine participants had intellectual and developmental disability and ASD diagnosis (Greene \& Bethune, 2021; Jimenez et al., 2014; Knight et al., 2013); 10 participants had ASD diagnosis (Johnson et al., 2015; McMahon et al., 2015; Tekin-İftar \& Olcay-Gül, 2017); It was observed that four participants had a diagnosis of multiple disabilities (Riesen et al., 2003; Smith et al., 2013) and two participants had a diagnosis of developmental disabilities (Rivera et al., 2017).

\section{Findings About Interventionists}

Information on implementers was provided in all of the studies. When the information about the implementers in the studies was examined, it was seen that in nine studies the special education teacher (e.g., Greene \& Bethune, 2021; Collins et al., 2017; Tekin-İftar \& Olcay-Gül, 2017); in four studies co-teacher (Britton et al., 2017; Heinrich et al., 2016; Johnson et al., 2015; Riesen et al., 2003); in three studies peer tutor (Britton et al., 2017; Heinrich et al., 2016, Jimenez et al., 2012); in four studies the researcher himself (Jimenez et al., 2009; McMahon et al., 2015; Rivera et al., 2017; Sazak-Pınar \& Merdan, 2016); in a study the teacher (Johnson et al., 2015); in another study a research assistant (Knight et al., 2013) implemented the intervention.

\section{Findings About Settings}

According to the findings all of the studies included the information about the settings in where the implementation was conducted. Seven studies took place in special education class (e.g., Jimenez et al., 2009; Rivera et al., 2017; Tekin-İftar \& Olcay-Gül, 2017); five studies took place in the general education class (e.g., Heinrich et al., 2016; Johnson et al., 2015; Riesen et al., 2003); five studies took place in the source room (support special education class) (e.g., Britton et al., 2017; Collins et al., 2011; Karl et al., 2013; Sazak-Pınar \& Merdan, 2016); one study took place in the school backyard (Collins et al., 2017); a study took place in the computer lab (McMahon et al., 2015) and a study took place in the teachers' room (Smith et al., 2013).

\section{Findings About the Research Models}

It was determined that eight of the studies included in this study were designed as the multiple probe model between behaviors (e.g., Karl et al., 2013; McMahon et al., 2015; Smith et al., 2013); seven of them were designed as the multi-probe model between participants (e.g., Collins et al., 2017; Heinrich et al., 2016; Rivera et al., 2017); two of them were designed as adaptive rotational applications model (Collins et al., 2007; Riesen et al., 2003). A study was designed with the multiple initiation models between behaviors (Johnson et al., 2015).

\section{Findings About Dependent Variables}

In the studies, "Force and energy" (Greene \& Bethune, 2021; Jimenez et al., 2012; Karl et al., 2013); "Energy conversions and environmental pollution" (Collins et al., 2017; Britton et al., 2017; Heinrich et al., 2016); "World of living" (Johnson et al., 2015; Rivera et al., 2017); "Systems in our body" (McMahon et al., 2015; Tekinİftar \& Olcay-Gül, 2017); "digestive" (Sazak-Pınar \& Merdan, 2016 ); "Reproduction, growth and development in living organisms" (Jimenez et al., 2014; Smith et al., 2013); "Matter and heat" (Knight et al., 2013), "DNA and genetic code" (Riggs et al., 2013); "Pure substance and mixtures" (Collins et al., 2011) had been determined for target outcomes for the science class.

\section{Findings about Independent Variables}

In the studies; the constant time delay teaching method in five studies (e.g., Greene \& Bethune, 2021; Riggs et al., 2013; Smith et al., 2013); simultaneous prompting teaching method in four studies (e.g., Britton et al., 2017; Karl et al., 2013; Tekin-İftar \& Olcay-Gül, 2017); embedded teaching and constant time delay method in three studies (Johnson et al., 2015; Jimenez et al., 2014; Jimenez et al., 2012); simultaneous prompting method with embedded teaching methods in a study (Heinrich et al., 2016); the story telling with technology-supported teaching and simultaneous prompting teaching methods in a study (Rivera et al., 2017); the constant time delay teaching method with augmented reality application in one study (McMahon et al., 2015) and the constant time delay teaching method with a graphic organizer were used in other studies (Knight et al., 2013; Sazak-Pınar \& Merdan, 2016).

\section{Other Findings}

In the 16 studies included in the analysis, application reliability data were collected in at least $10.5 \%$ of all sessions (range $=10.5-100$ ). In three studies although the application reliability was collected, no information 
was given about how much reliability data was collected in the sessions (Britton et al., 2017; Collins et al., 2007; Jimenez et al., 2012). In addition to this, interobserver agreement data were collected in at least $20 \%$ of all sessions (range $=20-100$ ). In three studies although interobserver agreement was collected, no information was given about how much reliability data was collected in the sessions (Britton et al., 2017; Collins et al., 2007; Jimenez et al., 2012). In the 16 studies examined in this study, interobserver agreement data were collected in at least $20 \%$ of all sessions (range $=20-100$ ). In three studies although interobserver agreement was collected, no information was given about how much reliability data was collected in the sessions (Britton et al., 2017; Collins et al., 2007; Jimenez et al., 2012).

It was determined that social validity data were collected in 12 studies included in the study, and however social validity data were not collected in seven studies (e.g., Britton et al., 2017; Karl et al., 2013; Knight et al., 2013). It was determined that monitoring/maintaining data were collected in 17 of the studies obtained, and while the monitoring/maintaining data were not collected in two studies (McMahon et al., 2015; Riesen et al., 2003). It was determined that generalization data were collected in 10 studies included in the study, while generalization data were not collected in nine studies (e.g., Greene \& Bethune, 2021; Johnson et al., 2015; Smith et al., 2013).

\section{Discussion}

In the research, 19 studies using single-subject experimental research method in which errorless teaching methods are applied in teaching science subjects and concepts to students with disabilities were examined in terms of certain variables and analyzed descriptively. The research findings reveal that errorless teaching methods are effective in teaching science subjects and concepts to students with disabilities, ensuring the maintaining and generalization of the subjects were taught. The findings obtained from the research match up with the findings of existing systematic review studies (Apanasionok et al., 2019; Spooner et al., 2011; Spooner et al., 2012; Taylor et al., 2019).

All of the participants were students with severe disabilities in a study was conducted by Spooner et al. (2012). In this context, these findings obtained from the study support the findings of current systematic review studies. Considering the settings in which the research is carried out, although students' level of disability is moderate or severe, they receive education with their peers in general education schools, which means that the inclusive practices are more advanced in the other countries compared to Turkey.

When the studies are examined in terms of research models, it is seen that in almost all 19 studies, multiple probe and multiple baseline designs, one of the single-subject experimental research designs, were used to investigate the effectiveness of errorless teaching methods. The most important reason for this situation can be stated as the fact that each of the students with disabilities has different development characteristics.

When the dependent and independent variables of the research included in the study are examined, it is seen that the most target teaching subjects in the fields of science were physics, chemistry and biology. The most frequently used errorless teaching methods in teaching these subjects was constant time delay teaching and simultaneous prompting teaching methods. This kind of studies can be conducted with students with moderate and severe disabilities in Turkey, too.

Although this research includes national and international literature, but there are only two national studies that meets the research criteria. This may be an indication that academic skills in our country are mostly studied with students with mild disabilities. When the participant characteristics of the studies included in this research are examined, it is seen that high-level academic skills are taught to children with moderate and severe disabilities in other countries.

This systematic review research has some limitations. First of all, the studies included in the scanning process were not subjected to a detailed evaluation filter in terms of their methodological qualities in terms of design standards mentioned in Horner et al., (2005) and Kratochwill et al. (2013). However, in the creation of descriptive analysis codes Horner et al. (2005) research has been taken into account. The second one is that only studies published in peer-reviewed journals were included in the research and graduate theses and dissertations were not included.

\section{Conclusion}

The findings obtained from this research show that errorless teaching methods are effective in teaching science subjects and concepts to students with different disabilities who are at different grade levels and age groups. These findings match up with the previous systematic review findings on the subject and are thought to 
enrich the existing literature in terms of some of the points mentioned above. As a result, it is seen that teachers can teach the science subjects and concepts, which is a high-level academic skill, to the students with disabilities by using errorless teaching methods in their classroom settings.

\section{Suggestions}

Based on the findings, it may be suggested to researchers to plan and conduct studies that compare the effectiveness and efficiency of different errorless teaching methods. Errorless teaching methods can also be included in the content of teachers' in-service training programs. Finally, systematic review studies can be carried out to determine which teaching methods are used in teaching science subjects in special education.

\section{Author's Contributions}

This research has been prepared in the context of a class. The authors determined the topic together. Then, the first author performed the scanning and analysis of the data under the second author's instructions. The second author made the reliability studies of the research and followed all the works of the first author step by step. Since most of the studies included in the research were in English, the studies were also checked by the second author in terms of language. The English writing of the article also belongs to the second author. Both authors then wrote the research. The second author is also the author responsible for the publication of the research and conducted all correspondence. 